\title{
Achados do Matadouro de São Cristóvão: o artefato arqueológico virtualizado no Museu Histórico Nacional
}

Findings of the São Cristóvão Slaughterhouse: the archaeological artifact virtualized at the Museu Histórico Nacional

http://dx.doi.org/10.1590/1982-02672019v27e02

MARIA DE SIMONE FERREIRA'

https:/ / orcid.org/0000-0002-0616-6736

Museu Histórico Nacional / Rio de Janeiro, RJ, Brasil

ISABELA MARIA OLIVEIRA BORSANI²

https: / / orcid.org/0000-000 1-9544-0057

Museu Histórico Nacional / Rio de Janeiro, RJ, Brasil

RESUMO: Este artigo parte da exposição "Achados da Leopoldina: arqueologia urbana na era digital", sediada em 2017 no Museu Histórico Nacional, para analisar o lugar e o tempo da musealização e da exposição do objeto arqueológico oriundo do sítio Matadouro Público de São Cristóvão, no Rio de Janeiro. Para tanto, à luz da legislação específica do campo do patrimônio arqueológico e de suas contingências, reflete-se sobre o uso da virtualidade como recurso expográfico em um caso no qual a pesquisa arqueológica desembocou em uma solução de exposição centrada na linguagem virtual com fins de divulgação da coleção, deixando a cargo do acervo do Museu Histórico Nacional encarnar vicariamente a materialidade dos artefatos arqueológicos do antigo matadouro público da cidade do Rio de Janeiro.

PALAVRAS-CHAVE: Matadouro Público de São Cristóvão. Museu Histórico Nacional. Achados da Leopoldina: arqueologia urbana na era digital. Patrimônio arqueológico. Cultura material. Novas tecnologias de informação e comunicação.

\begin{abstract}
1. Museóloga pela Universidade Federal do Estado do Rio de Janeiro (Unirio), mestre e doutora em História Social da Cultura pela Pontifícia Universidade Católica do Rio de Janeiro (PUC-Rio). Atua como técnica em museologia na Reserva Técnica do Museu Histórico Nacional. E-mail: <mariadsferreira@gmail. com>

2. Publicitária pela Universidade Federal do Rio de Janeiro (UFRJ), possui mestrado profissional em Comunicação Digital para o Patrimônio Cultural, pela Universidade de Roma 1 (La Sapienza), mestranda em Comunicação e Cultura (UFRJ). Responsável pela Assessoria de Comunicação do Museu da República. E-mail: <isaborsani@gmail. com>
\end{abstract}


ABSTRACT: This paper is based on the exhibition Findings of Leopoldina: urban archaeology in the digital era, hosted by the Museu Histórico Nacional, in 2017. It aims to analyze the place and time of the musealization and the exhibition of the archaeological object deriving from the São Cristóvão Public Slaughterhouse site, in Rio de Janeiro. Therefore, given the specific legislation in the field of archaeological heritage and its contingencies, we reflect upon the use of virtuality as an exhibition resource in a case in which archaeological research led to a particular design solution for the exhibition, consisting of the dissemination of the collection by means of a virtual language, leaving to the objects of the Museu Histórico Nacional to vicariously embody the materiality of the archaeological artifacts of the ancient public slaughterhouse of the city of Rio de Janeiro.

KEYWORDS: São Cristóvão Public Slaughterhouse. Museu Histórico Nacional. Findings of Leopoldina: urban archaeology in the digital era. Archaeological heritage. Material culture. New information and communication technology. 
INTRODUÇÃO

Achados da Leopoldina - Arqueologia Urbana na Era Digital propõe ao público do Museu Histórico Nacional uma experiência inovadora de imersão e apreciação de uma coleção de peças encontradas no sítio arqueológico do Matadouro de São Cristóvão durante as recentes obras de expansão da malha metroviária carioca.

Trata-se de um trabalho inédito no Brasil, no qual o visitante é provocado a refletir sobre o passado olhando pelas lentes do futuro. $\bigcirc$ uso de diferentes plataformas e mídias instiga o público a estabelecer um elo lúdico, sensorial e interativo com o acervo, capaz de ressignificar a própria relação do observador com o objeto. ${ }^{3}$

Ao adentrar o espaço expositivo de "Achados da Leopoldina: arqueologia urbana na era digital", o visitante do Museu Histórico Nacional (MHN) deparavase com essas palavras introdutórias ao percurso que se seguiria ao longo da exposição. Depreendia-se do texto, desde o primeiro momento, a expectativa dos organizadores em proporcionar uma experiência expositiva transformadora em torno dos artefatos oriundos do sítio arqueológico do Matadouro de São Cristóvão, além das promessas de estabelecimento de novos elos entre observador e objeto, primando pela "reconstrução de passados a partir de novas tecnologias". ${ }^{4}$ É o que os organizadores indicarão mais adiante na exposição, no intuito de instigar uma espécie de curadoria colaborativa entre especialistas e visitantes, próxima do conceito de enciclopédia virtual e inteligência coletiva. ${ }^{5}$

Das percepções surgidas ao visitar a exposição, entre seus textos, objetos, reproduções e recursos midiático-interativos, seguiram-se os questionamentos que orientam a discussão central deste artigo: qual o papel do uso da linguagem virtual na expografia em que pese a tradicional materialidade do objeto musealizado? Que novas formas de recepção pode a linguagem expográfica calcada no virtual engendrar na visita ao museu? Que ressignificações podem sofrer os conceitos de "valor de antiguidade" e "aura" atrelados ao objeto arqueológico perante sua atualização por meio da virtualidade? Por fim, de que modo a linguagem virtual na expografia pode alterar o valor de culto atribuído à cultura material musealizada e as aspirações da sociedade em relação ao museu?

Cruzaram-se na linguagem expositiva de "Achados da Leopoldina: arqueologia urbana na era digital" exigências legais do âmbito do patrimônio arqueológico que condicionaram a formação dessa coleção de bens móveis arqueológicos, como resultado de um processo de pesquisa arqueológica do sítio em si. Por fim, também devido a exigências da lei, a pesquisa se consubstanciou na exposição de seus artefatos, neste caso, no formato virtual, encetando a problemática do estatuto do
3. Prefeitura da Cidade do Rio de Janeiro (2017, contracapa).

4. Ibid., p. 4

5. Ibid., p. 4 
6. Projeto de salvamento... (2012).

7. Machado; Scaramella; Rodrigues (2009). objeto arqueológico em um museu de história nos dias de hoje, do uso de novas tecnologias de informação e comunicação (NTIC) em exposições de museu, além da linguagem museológica fundada na presença virtual da musealia ausente.

Mais do que fornecer respostas imperativas para as questões aqui elencadas, este artigo tem por objetivo suscitar reflexões acerca do emergente uso de novas tecnologias de informação e comunicação como solução expográfica em museus e sua implicação quanto a possíveis ressignificações do papel do objeto musealizado, à luz do caso de "Achados da Leopoldina: arqueologia urbana na era digital". Com vistas a elucidar respostas possíveis às questões que se abriram com essa exposição de curta duração, sediada no MHN em 2017 e elaborada pelo Instituto Cultural Cidade Viva (ICCV), lançamo-nos na tarefa de percorrer os meandros do processo de musealização dos artefatos provenientes da região da estação da Estrada de Ferro Leopoldina até culminar em sua exibição ao público. Para tanto, além da visitação mediada por curadores, consultamos o Projeto de salvamento arqueológico do Sítio Matadouro Imperial de São Cristóvão, arquivado no Instituto do Patrimônio Histórico e Artístico Nacional (Iphan), ${ }^{\circ}$ e aprofundamos os questionamentos motivados pelas inquietações quanto à ausência dos objetos originais, através do aporte teórico oriundo da história, da comunicação, da museologia e da filosofia.

Partimos da hipótese de que o aspecto sedutor das NTIC, cujo apelo abordaremos como "fetichista", permite que o uso deste tipo de ferramenta na expografia de museus muitas vezes se aparte da função de linguagem, tomando, por sua vez, o lugar do objeto musealizado. Compete então a este artigo refletir, a partir do caso da virtualização expográfica dos objetos arqueológicos expostos em "Achados da Leopoldina: arqueologia urbana na era digital", sobre o desafio que se coloca para os museus em termos de expografia a partir do desenvolvimento e da difusão das NTIC.

\section{ACHADOS DO MATADOURO DE SÃO CRISTÓVÃO: OS ANTECEDENTES MUSEAIS}

Em 8 de dezembro de 2009, os arqueólogos Vera Lúcia de Sá Machado, Nídia Rodrigues e Giovani Scaramella registraram no Cadastro Nacional de Sítios Arqueológicos (CNSA) o Matadouro Público de São Cristóvão, vindo à tona ao longo do Projeto de arqueologia para obra de construção da interligação entre as Linhas 1 e 2 do Metropolitano do Rio de Janeiro - Linha 1.? Esta primeira identificação de remanescentes do antigo matadouro público da cidade já indicava o grande potencial arqueológico do sítio, uma vez que havia sido encontrado durante o monitoramento 
e as prospecções de interligação do metrô diversificado material arqueológico - como louça, cerâmica, ossos de animais (gado bovino), moedas e vidros - referente ao período histórico do Império do Brasil, além das estruturas arquitetônicas do matadouro ${ }^{8}$ e de seu pórtico de entrada, que naquela ocasião estava em processo de tombamento pelo Instituto Estadual do Patrimônio Cultural (Inepac). ${ }^{9}$

A pesquisa arqueológica do antigo Matadouro Público de São Cristóvão abre-se como ponto nodal para pensar a memória desse sítio por intermédio das reminiscências do espaço fraturado, ou seja, através de coleções de artefatos e não propriamente das estruturas do sítio, ou da combinação de sítio mais objetos, que chegam ao conhecimento público pelo viés expositivo. A exposição "Achados da Leopoldina: arqueologia urbana na era digital", realizada no Museu Histórico Nacional (MHN) em 2017, como parte dos resultados da pesquisa arqueológica no referido sítio, funda-se como elemento central de nossa reflexão acerca desses "objetos herdados gerados no presente" 10 para pôr em xeque o valor de culto do achado arqueológico musealizado na condição de um acervo digital.

Antes, entretanto, de nos deter na solução expográfica da coleção de "Achados da Leopoldina, faz-se fundamental compreender as circunstâncias legais e institucionais que levaram à sua virtualização na exposição do $M H N$. A arqueologia de contrato encontra suas primeiras feições na lei n 3.924, de 26 de julho de 1961, que dispõe sobre os monumentos arqueológicos e pré-históricos nacionais, submetendo a propriedade dos bens arqueológicos à União e sua proteção ao Iphan, órgão ao qual se deve comunicar a intenção de realizar pesquisas e escavações arqueológicas, afora solicitar permissão e autorização para tanto. Os projetos de arqueologia de contrato se intensificarão com a resolução nº01, de 23 de janeiro de 1986, do Conselho Nacional de Meio Ambiente (Conama), que exigirá o Estudo de Impacto Ambiental (EIA) e o Relatório de Impacto Ambiental (Rima) para a obtenção de licença ambiental para execução de obras de engenharia civil, compreendendo-se aí igualmente o diagnóstico e o estudo de impactos potencialmente capazes de afetar o patrimônio arqueológico. ${ }^{11}$

Ao Iphan caberá regulamentar além da comunicação prévia, os pedidos de permissão e de autorização para o desenvolvimento de pesquisas de campo e escavações arqueológicas no país conforme a portaria $n^{\circ} 07$, de $1^{\circ}$ de dezembro de 1988. Essa portaria demonstra preocupação com a preservação do patrimônio arqueológico e, principalmente, no que concerne a este artigo, com a extroversão dos resultados do estudo arqueológico, deixando patente o caráter moderador desse tipo de pesquisa ao afirmar que a "perda física dos sítios arqueológicos poderá ser efetivamente compensada pela incorporação dos conhecimentos produzidos à Memória Nacional". ${ }^{12}$
8. Ibid., p. 73 .

9. Cf. Instituto Estadual do Patrimônio Cultural (2018).

10. Segundo definição de Meneses (apud Wichers, 2010, p. 251), estes seriam os objetos do passado que nos chegam a partir de pesquisas arqueológicas realizadas pouco antes ou paralelamente aos processos de musealização, por oposição aos "objetos herdados do passado", que já se encontram sob a guarda dos museus há muito tempo.

11. Caldarelli; Santos (19992000, p. 55).

12. Iphan (2002). 
13. Lima (2012, p. 71).

14. A área tornou-se popularmente conhecida como Leopoldina em razão da estação ferroviária construída pela Estrada de Ferro Leopoldina. Mello (2012, p. 46).
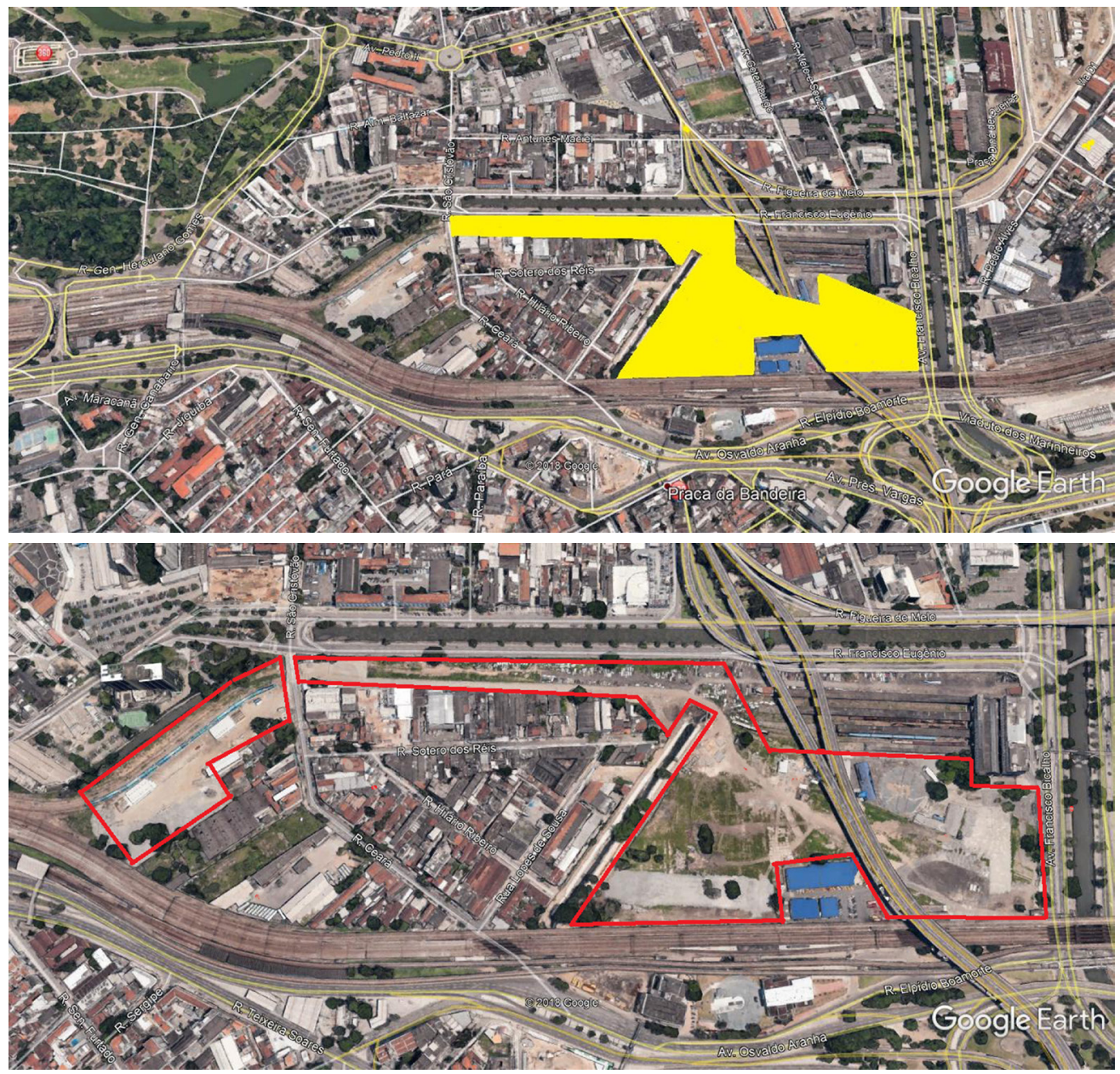

Figuras 1 e 2 - Localização do canteiro na Praça da Bandeira limitada pela Rua Francisco Eugênio, Avenida Francisco Bicalho, pela linha do trem e pelo canal paralelo à Rua Lopes de Souza. Fonte: Claudio Prado de Mello.

No bojo da expansão da malha metroviária carioca por ocasião do compromisso firmado entre o governo do estado do Rio de Janeiro e o Comitê Olímpico Internacional (COI), ${ }^{13}$ fez-se inevitável, a partir de 2012, nova intervenção na área da Leopoldina ${ }^{14}$ - região de entrecruzamento da Cidade Nova, da Praça da Bandeira e de São Cristóvão e onde se encontra o sítio do Matadouro de São Cristóvão (Figuras 1 e 2) - para que o empreendimento de interligação da Linha 4 Sul (Barra da Tijuca) e da Linha 1 (Estação General Osório) do Metrô do Rio pudesse se concretizar. A autorização para a realização de tais obras dependia, portanto, do licenciamento ambiental emitido pelo Instituto Estadual do Ambiente (Inea), o que, em última instância, comportaria igualmente o projeto de salvamento 
arqueológico para o sítio Matadouro de São Cristóvão, a ser analisado e acompanhado pelo Iphan, de maneira que o impacto sobre o patrimônio arqueológico fosse minimizado pela produção de conhecimento e pela guarda do material arqueológico.

Entretanto, em observância ao prazo estabelecido para a pesquisa em função do cronograma das obras de montagem da linha de pórticos da fábrica de aduelas, que ocupava o trecho da Leopoldina, fez-se imperativo suspender o salvamento até dezembro de 2015, quando terminaria a atividade da fábrica. Maurício Rizzo, presidente da concessionária Rio Barra, encarregada das obras, encaminha em 20 de agosto de 2013 à Superintendência do Iphan-RJ um caderno intitulado Proposta de recomendações de proteção para o sítio arqueológico do Matadouro Imperial - Leopoldina, ${ }^{15}$ preparado pelo arqueólogo Claudio Prado de Mello, responsável pela empresa contratada para o serviço de pesquisa arqueológica - a Terra Brasilis, no qual se sugere o monitoramento e a cobertura temporária das estruturas do sítio até que se pudesse retomar a pesquisa interventiva.

A proposta é aceita por todas as partes envolvidas - Iphan, Consórcio Linha 4 Sul, Terra Brasilis, Inepac, RioTrilhos. Na ocasião, acertaram-se detalhes do procedimento de proteção do sítio, e emergiram alguns problemas de ordem institucional em termos da guarda do material arqueológico suscitados por Claudio Prado de Mello, que esboçou a intenção de levar as peças para o Instituto de Pesquisa Histórica e Arqueológica do Rio de Janeiro (lphari), o que foi contestado por Regina Coeli Pinheiro, assessora de arqueologia do Iphan-RJ, ao reafirmar que o endosso institucional havia sido conferido ao Laboratório de Arqueologia Brasileira (LAB), conforme portaria de permissão da pesquisa. ${ }^{16}$

Em missiva da advogada do LAB, Carla Rosa, para o Iphan, relata-se o fato de Claudio Prado de Mello ter se recusado a assinar o compromisso com - LAB de arcar com a taxa administrativa de 5\% do valor total do projeto para obtenção do endosso institucional após a publicação da portaria $n^{\circ} 12$, de 11 de março de 2013, no Diário Oficial da União. ${ }^{17}$ A sra. Rosa apela ao Iphan não só para que notifique o arqueólogo responsável quanto à inadimplência contratual, mas também para denunciar que Prado de Mello "externou que não pretende entregar o referido material ao LAB", interessando-lhe "depositá-lo em lugar outro, ainda sem permissão para funcionamento", 18 ou seja, no lpharj. De acordo com o próprio Claudio Prado de Mello, o LAB teria servido como uma espécie de possibilitador para a aprovação do projeto de pesquisa enquanto - Ipharj estava em vias de ser credenciado pelo Iphan como instituição de guarda. ${ }^{19}$
15. Mello (2013, p. 424429).

16. Ata de reunião... (2012, p. 439).

17. Rosa (2013, p. 420).

18. Ibid., p. 421.

19. Mello (2016, p. 963). 
20. Rizzo (2016, p. 903905).

21. Ribeiro (2016, p. 1418). 22. Ibid., p. 1419.
Por fim, ocorre que, em 15 de janeiro de 2016, Mônica da Costa, superintendente substituta do Iphan-RJ, encaminhará o Ofício nº 0095 à Terra Brasilis-1pharj, ao secretário de Estado de Transportes, ao gerente do Departamento de Obras Sul da RioTrilhos e ao presidente da concessionária Rio Barra, acusando o recebimento dos relatórios parciais do salvamento arqueológico no Matadouro de São Cristóvão e solicitando o envio do relatório final do projeto para encerrar a portaria de permissão e, ainda, a entrega do material arqueológico ao $L A B$ e a atualização da ficha de registro do sítio no CNSA. Seguiu-se daí a transferência da coleção do Sítio Matadouro de São Cristóvão para o LAB, efetuada por técnicas do Iphan e por funcionários do Metrô Rio nos primeiros dias de fevereiro de 2016.

material foi, assim, devidamente acomodado em caixas e transportado pela concessionária Rio Barra em duas remessas, perfazendo 575 volumes, até o $L A B$, que as recebeu nos dias 5 e 12 de fevereiro. ${ }^{20} O$ parecer $n^{\circ} 174$ da Assessoria Técnica de Arqueologia do Iphan-RJ, datado de 27 de maio de 2016 e redigido por Maria Christina Rodrigues, refere-se ao Relatório final do projeto de salvamento arqueológico do Sítio Matadouro Imperial de São Cristóvão, protocolado por Claudio Prado de Mello no Iphan em 25 de maio de 2016, e inaugura uma sucessão infindável de cobranças do Iphan em relação ao trabalho técnico da Terra Brasilis, cuja solução definitiva soa estar, ainda hoje, distante de se efetivar.

Como não se obteve retorno a contento da parte da Terra Brasilis nos meses consecutivos, o Ministério Público Federal (MPF) foi acionado para vistoriar o LAB com o objetivo de verificar as condições de acautelamento do acervo, questionadas por Claudio Prado de Mello, assim como de estabelecer um acordo para finalizar o processamento das peças e sua exposição. As instituiç̧̃es implicadas expuseram seus posicionamentos ante o imbróglio que se estabelecera, e o procurador federal Sérgio Suiama solicitou ao representante da Terra Brasilis que concluísse a catalogação do material, encaminhando na sequência o relatório finalizado ao Iphan. ${ }^{21}$

Na ocasião, José Carlos Barros, do ICCV, acompanhou a vistoria e explicou que o ICCV havia sido contratado para realizar a exposição da coleção, já dispondo inclusive de uma relação de peças discriminadas para integrátla. ${ }^{22} \mathrm{~A}$ preocupação de José Carlos Barros quanto à conclusão técnica do trabalho de arqueologia devia-se ao fato de que a exposição já fora adiada anteriormente por esse mesmo motivo, o que resultava em uma série de desacordos sobre o local de sua realização dada a agenda indefinida - já haviam sido cogitados o Museu de Arte do Rio, o Museu do Amanhã e, naquele momento, a Casa França-Brasil -, mas, sobretudo, a situação toda tornavase mais premente por conta da perspectiva de mudança no governo municipal e da exiguidade do prazo para execução da dotação dos recursos provenientes de renúncia fiscal do Imposto sobre serviços (ISS) que financiariam a exposição. 
Ao ouvir sobre a listagem de peças na posse do gestor do ICCV, as funcionárias do Iphan pronunciaram-se dizendo desconhecer sua existência e expressaram o desejo de que ela passasse pelo crivo da instituição antes de figurar na exposição planejada. Além do que, Mônica da Costa alegou que a prioridade demandada por José Carlos Barros para o tratamento e registro das peças selecionadas para a exposição fugia ao escopo de atuação do Iphan, e que poderia até se reverter contrariamente ao órgão. Em vista de tais considerações, Sérgio Suiama sugeriu ao sr. Barros resolver a questão diretamente com Claudio Prado de Mello. ${ }^{23}$

MPF exarará em 24 de março de 2017 um Termo de Ajustamento de Conduta (TAC) devidamente assinado pelos representantes do LAB e da Terra Brasilis, decorrente da instauração de um Inquérito Civil referente à proteção do patrimônio arqueológico do sítio Matadouro de São Cristóvão. Suiama estabelece datas-limite para o cumprimento das obrigações pendentes do compromissário e dedica a Cláusula Terceira ao tema da exposição das peças, explicitando que:

Para fins de educação patrimonial e mediante prévia autorização específica do Iphan, o COMPROMISSÁRIO poderá emprestar parte do acervo arqueológico para a realização de exposição aberta ao público, assumindo ele, na ocasião, porém, total responsabilidade por quaisquer danos que venham a ser causados ao patrimônio em decorrência do evento. ${ }^{24}$

Eis que, sem haver concluído a curadoria do material com a quantificação e a contextualização das peças com a aprovação do Iphan, o planejamento da exposição dos achados arqueológicos oriundos da Leopoldina, que jogariam luz sobre parte significativa dos usos da cidade e do cotidiano da vida na corte imperial, precisou ser inteiramente revisto do ponto de vista técnico, ainda que não conceitualmente. Estabelecido o impasse sobre a liberação do acervo para a exposição, afora a morosidade para o encerramento da pesquisa e o prazo por diversas vezes renegociado para execução da dotação orçamentária disponível ao ICCV, impôs-se a necessidade de uma solução prática do prisma museográfico para suprir a ausência dos artefatos arqueológicos retidos pelo Iphan no LAB. Do desafio de expor os achados da Leopoldina sem contar com sua presença in loco, desenhou-se a possibilidade de explorar os recursos tecnológicos existentes para equacionar o problema curatorial. Coube ao Museu Histórico Nacional, por fim, abrigar essa exposição. 
25. Cf. Site da Università di Roma, disponível em: https://bit.ly/2RBYGmu. Acesso em: 4 dez. 2018.

26. Cf. Site do Icom, disponível em: https://bit. ly/11DYKfl. Acesso em: 4 dez. 2018.

27. Unesco (2015, p. 8).

28. Meneses apud Wichers (2010, p. 246).

29. Pomian (1988, p. 60).

30. Cf. Perthes (1857).

31. Hernández (2010, p. 36); Meneses apud Wichers (2010, p. 246).

32. Pomian (1988, p. 58).

\section{OS ARTEFATOS MEDIADOS NO MUSEU HISTÓRICO NACIONAL}

O uso das NTIC vem sendo a cada dia mais estimulado na preservação, no estudo e na difusão do patrimônio cultural por proporcionar acessibilidade, possibilidades múltiplas de armazenamento e cruzamento de informações e documentos, dentre outras aplicações. Embora não incomum nas expografias das últimas décadas, vale sublinhar a expansão da mediação tecnológica no campo do patrimônio cultural hoje, destacando-se, por exemplo, o curso de pósgraduação da Universidade de Roma, cidade onde se encontra o maior número de sítios arqueológicos do mundo, dedicado ao estudo do uso de novas tecnologias digitais na comunicação do patrimônio cultural. ${ }^{25}$ Ademais, o tema proposto pelo Conselho Internacional de Museus (lcom) para o Dia Internacional dos Museus em 2018 foi "Museus hiperconectados: novas abordagens, novos públicos", 26 o que também aponta para um reconhecimento do setor de museus das transformações tecnológicas que nos circundam. Não se pode deixar de citar, igualmente, a Recomendação referente à proteção e promoção dos museus..., publicada pela Unesco em 2015, cujo item 19 sugere aos Estados membros o apoio aos museus no compartilhamento e na disseminação do conhecimento a partir das "mudanças trazidas pela ascensão das tecnologias da informação e comunicação (TIC)", que "oferecem oportunidades para os museus em termos de preservação, estudo, criação e transmissão do patrimônio e do conhecimento relacionado". ${ }^{27}$

Assim, do ponto de vista dos museus, e mais especificamente daqueles destinados à musealização da arqueologia, não se estranha sua adaptação, em especial museográfica, a essas novas possibilidades, uma vez que o recurso à linguagem de apoio através do uso de "objetos criados" 28 - ou seja, de objetos concebidos com a finalidade de intermediar a comunicação no ambiente do museu arqueológico de forma complementar à coleção existente - ocorre desde a segunda metade do século XIX com o surgimento dos "museus arqueológicostecnológicos", 29 quando da descoberta da antiguidade do homem pré-histórico ${ }^{30}$ e da colonização de novas regiões e povos culturalmente diferentes do referencial europeu.

Nesse modelo de museu de arqueologia classificado por Krzyzstof Pomian costuma-se recorrer ao emprego do maior número possível de recursos imagéticos, textuais e de caráter científico, tais como mapas, dioramas, cenarizações, modelos e maquetes, ${ }^{31}$ para compor o quadro de informações sobre a cultura material exposta e, assim, amparar o visitante quanto à representação do passado desses objetos, muitas vezes repetitivos, de uso ordinário e raramente excepcionais. ${ }^{32}$ 
Nesse sentido, a exposição "Achados da Leopoldina: arqueologia urbana na era digital" não se furtará de lançar mão dos artifícios digitais para permitir o acesso às peças arqueológicas do Matadouro de São Cristóvão, impossibilitadas de serem expostas em sua materialidade, e alargar a ressonância dos resultados da pesquisa arqueológica para a sociedade.

Cabe perguntar, entretanto, em que medida a linguagem virtual que proporciona a representação do objeto, prescindindo por completo de sua materialidade como coisa em si, serve à ampliação da experiência sensível com o artefato material - como um molde de gesso serviria para completar uma escultura de mármore em ruínas - e em que medida o recurso aplicado ao objeto a fim de potencializar sua materialização e contextualização não pode, por vezes, no caso da tecnologia de representação virtual, fazer as vezes do próprio objeto, apartandose de seu referencial original a partir do qual toda pesquisa, preservação e difusão tem fundamento. Retornaremos a esta problematização mais adiante, após elucidarmos os aspectos da exposição tal como foi apresentada ao visitante do Museu Histórico Nacional.

"Achados da Leopoldina: arqueologia urbana na era digital", como exposição de curta duração, ocupou duas salas do MHN, somando cerca de $480 \mathrm{~m}^{2}$, em volta do Pátio dos Canhões, no térreo do prédio histórico. Para integrar o programa de exposições do $M H N$, esta exposição produzida externamente à casa precisou compatibilizar-se com a missão e a visão institucionais no que diz respeito à produção de conhecimento acerca da história, da cultura material e da sociedade no Brasil. Em contrapartida, contribuiu para promover a mobilização coletiva voltada à valorização da consciência histórica e do direito ao patrimônio cultural do Brasil. ${ }^{33}$

A exposição parte, assim, da seleção de oitenta peças de um universo de 200 mil itens encontrados no sítio arqueológico Matadouro de São Cristóvão - como garrafas de vidro ou em stoneware com ou sem conteúdo preservado, louças e porcelanas, cachimbos, escovas de dente em osso e marfim, moedas, botões, pratos, peças em ouro, material malacológico, artefatos líticos e outras mais - que visam a ilustrar os costumes e comportamentos do século XIX no Rio de Janeiro. Conforme explicado anteriormente, devido à impossibilidade de trazer em presença material os artefatos arqueológicos da Leopoldina e também à obrigatoriedade da extroversão dos resultados da pesquisa ao público, a curadoria optou, em substituição à exposição dos objetos arqueológicos, então embargados pelo Iphan, pela representação destes objetos por meio das seguintes técnicas de reprodução digital: holografia, realidade aumentada, óculos de visão 3D, anáglifos, $Q R$ codes e impressões 3D, o que, conforme 
34. Prefeitura da Cidade do Rio de Janeiro (2017, p. 5).

35. Ibid., loc. cit. explicita o catálogo da exposição, permite "uma interação potencializada pela tecnologia" ${ }^{34} \mathrm{e}$

um contato mais livre e interessado entre o grande público e o objeto museal, uma relação construída pelo toque, pela curiosidade, pela experiência sensitiva mediada por tecnologias que atraem cada vez mais o público, seja ele infantil, jovem ou adulto. ${ }^{35}$

circuito de visitação foi organizado em onze conjuntos interativos correspondentes ao tipo de objeto exposto, a saber: introdução; azulejos; utensílios domésticos e peças decorativas; garrafas e vasilhames; higiene, beleza e perfumaria; cachimbos; diversidades; espaço lúdico; audiovisual; salão de holografias; e Matadouro Imperial - realidade aumentada (Figuras 3 e 4). Em cada um destes conjuntos, os elementos das coleções, que podem ser vistos em fotografia no catálogo da exposição distribuído ao público, foram na mostra retratados com o uso das tecnologias citadas e acompanhados, em geral, por textos explicativos e peças provenientes da Reserva Técnica do MHN.

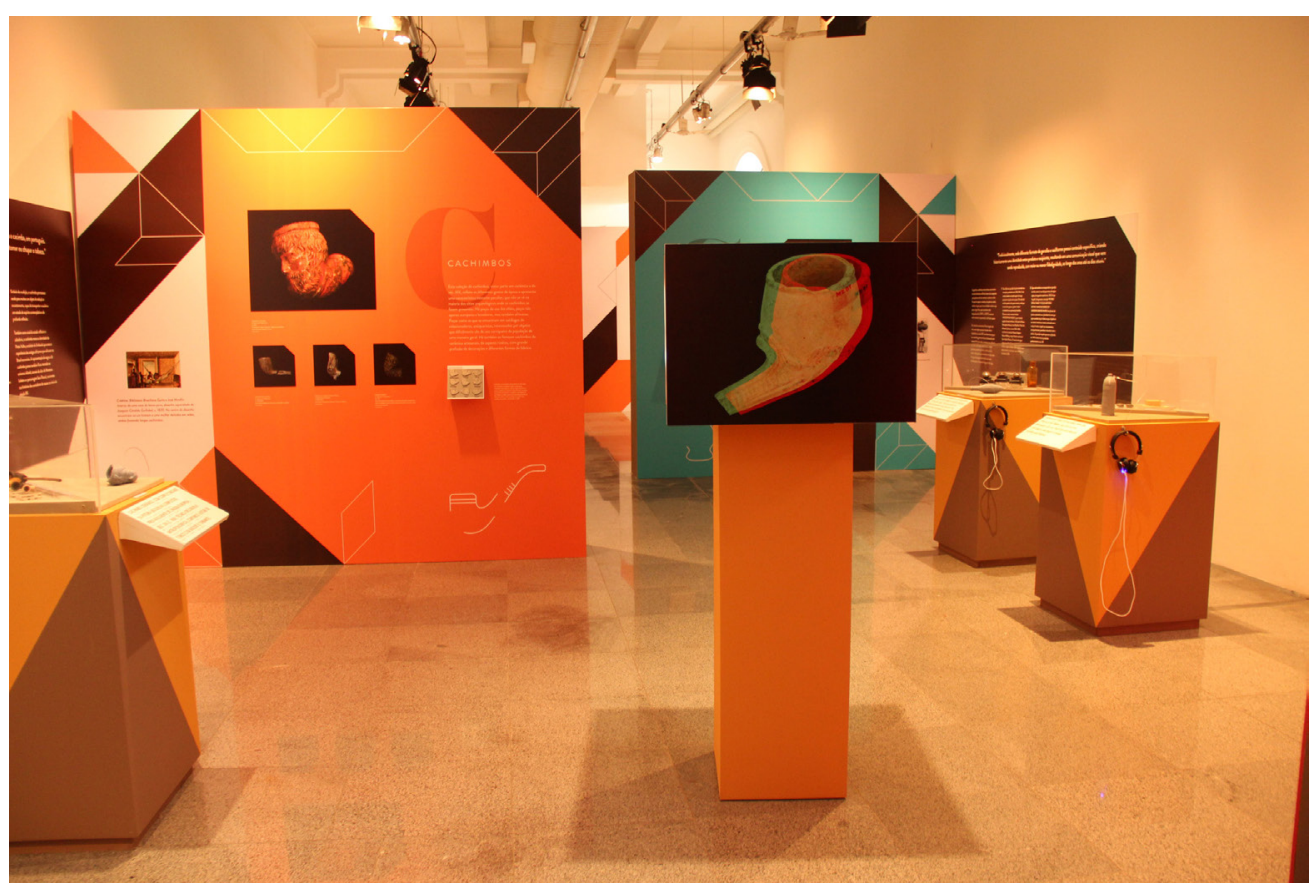

Figura 3 - Visão geral da exposição "Achados da Leopoldina". Fotografia: Museu Histórico Nacional//bram/MinC. 


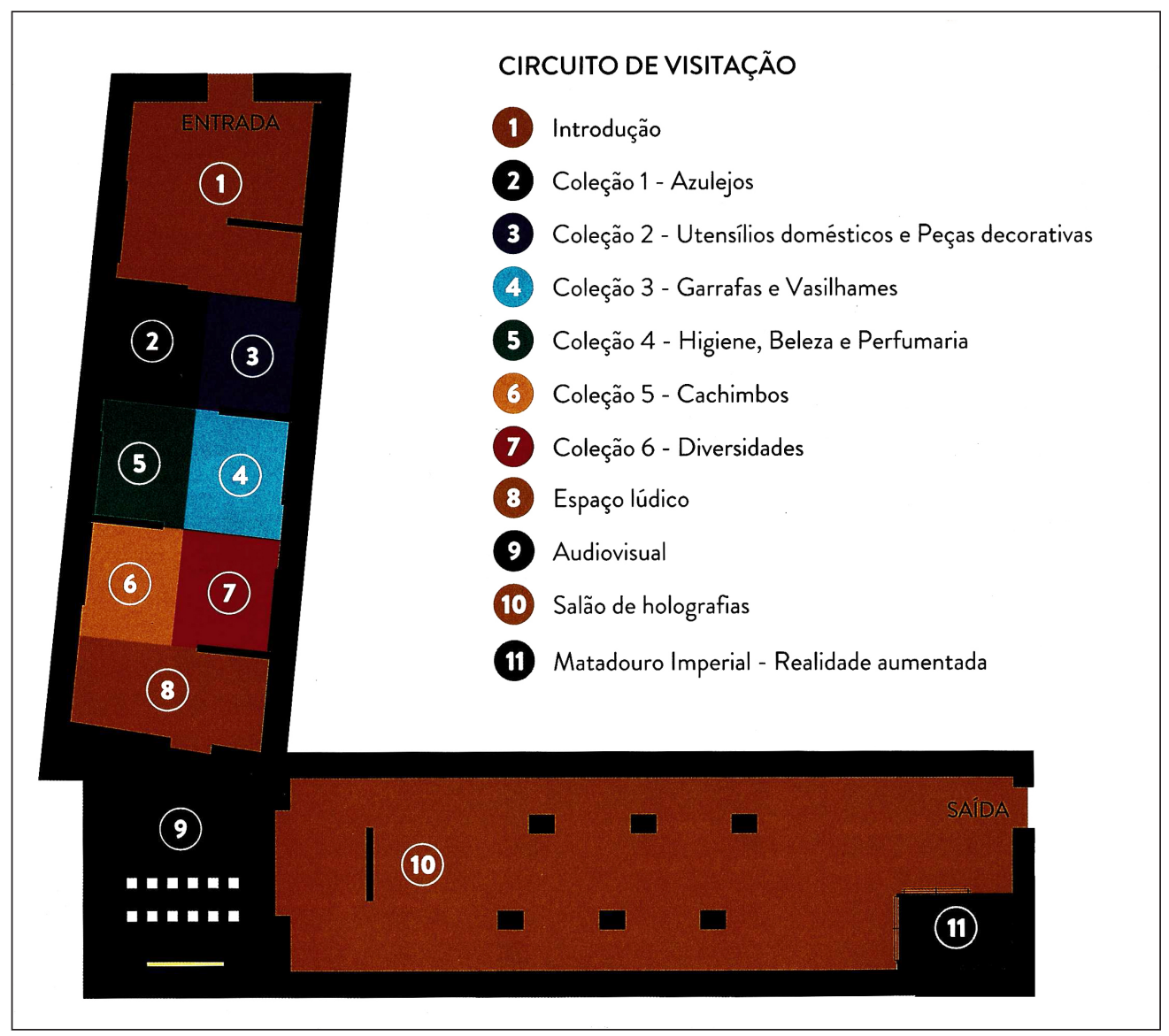

Figura 4 - Planta baixa exposição "Achados da Leopoldina". Fonte: Catálogo da exposição "Achados da Leopoldina: arqueologia urbana na era digital" (Prefeitura da Cidade do Rio de Janeiro, 2017).

No primeiro ambiente, introdutório, viam-se textos e fotografias de alguns dos objetos encontrados, bem como do sítio arqueológico em processo de escavação, somados a textos impressos sobre as paredes e divisórias. As imagens e os textos reportavam-se aos objetos encontrados, e que estariam retratados por meio das novas tecnologias de comunicação e informação ao longo do percurso adiante. Já era possível, neste ambiente, ter o primeiro contato com um dos recursos digitais de expografia, no caso, a impressão 3D, que corporificava em um molde de resina de poliuretano uma escova de dente originalmente em marfim com cerdas de material orgânico, provavelmente francesa, do século XIX. Cabiam então, para representar a escova original, uma fotografia em grande dimensão e o recurso tecnológico citado. 
Ao longo dos ambientes seguintes, podia-se enxergar a tridimensionalidade dos objetos arqueológicos a partir do uso de óculos 3D. Por exemplo, com a tecnologia de anáglifos, visualizavam-se imagens impressas e dispostas em totens na altura dos olhos do visitante. Assim ocorreu com o fragmento de cachimbo, de 1880, com decoração de origem alemã com a efígie do ex-presidente norte-americano Ulysses S. Grant (Figura 5), ou um crânio bovino, sem datação, ambos também virtualizados com a holografia (Figura 6). A impressão 3D trouxe à materialidade uma garrafa de grés, fabricada pela Wynand Fockink Amsterdam, Holanda, no século XIX (Figuras 7 e 8). Por meio da leitura de código QR (Quick Response) através de celulares, os visitantes podiam observar nas telas de seus telefones portáteis a tridimensionalidade dos artefatos retratados no catálogo promocional - na medida em que moviam o celular, alteravam o ângulo de visão do objeto impresso em duas dimensões. Por fim, com a tecnologia de vídeo com realidade aumentada projetou-se o Matadouro de São Cristóvão, que poderia ser visto em profundidade e interatividade, como nos videogames 3D, a partir de óculos especiais ofertados aos visitantes.

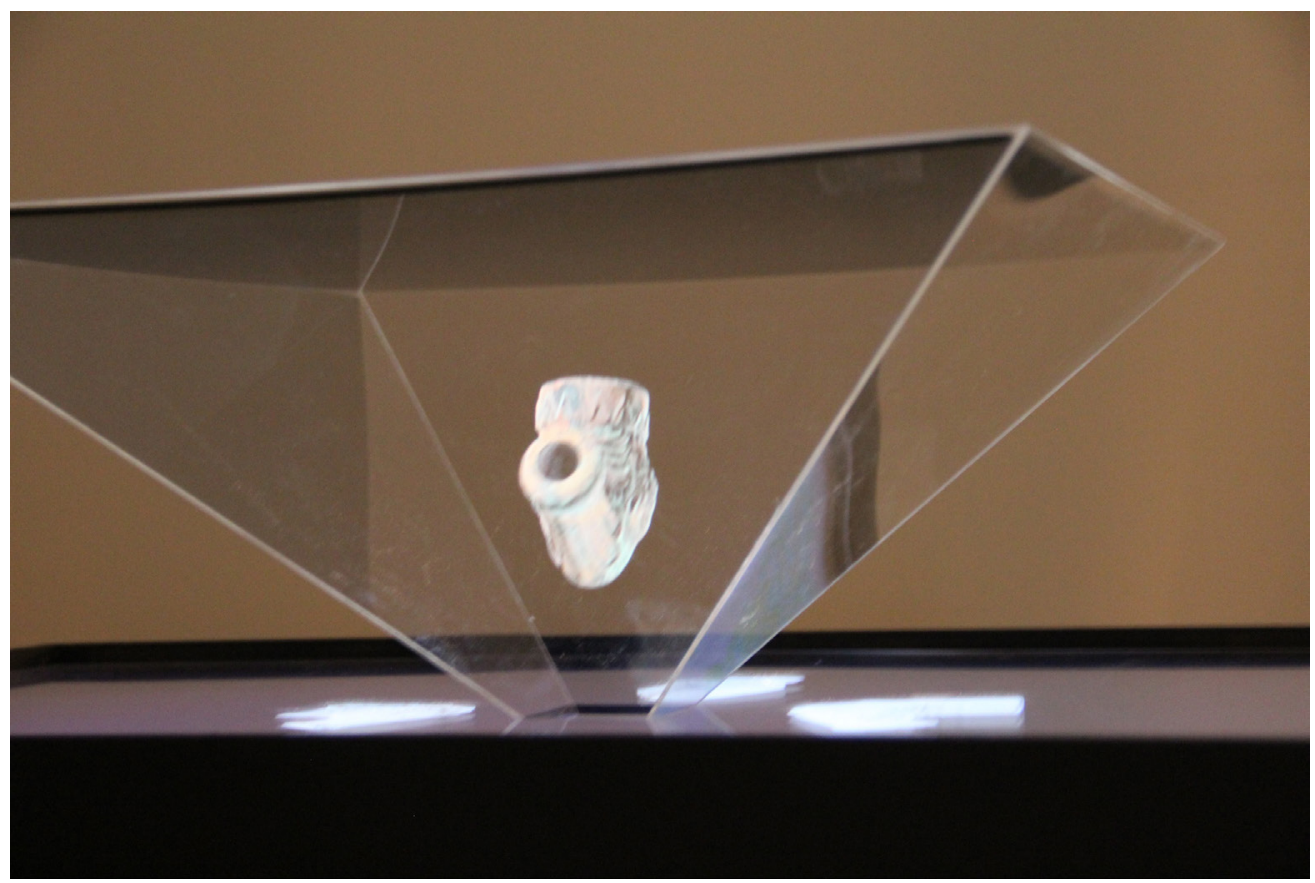

Figura 5 - Reprodução holográfica de fragmento de cachimbo, de 1880. Fotografia: Museu Histórico Nacional//bram/MinC. 


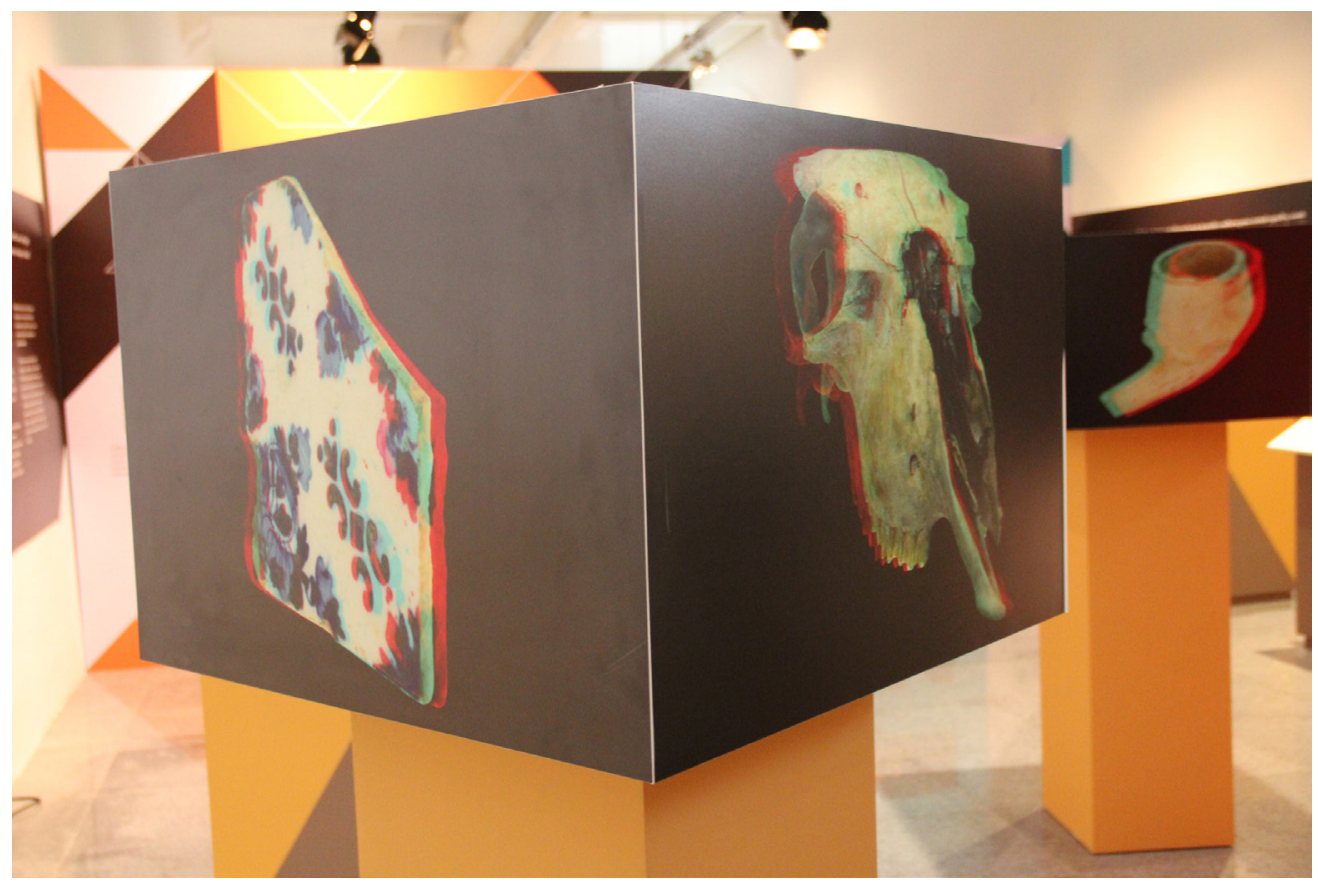

Figura 6 - Imagem 3D anaglífica de azulejo de padrão estampilha e crânio bovino. Fotografia: Museu Histórico Nacional/lbram/MinC.

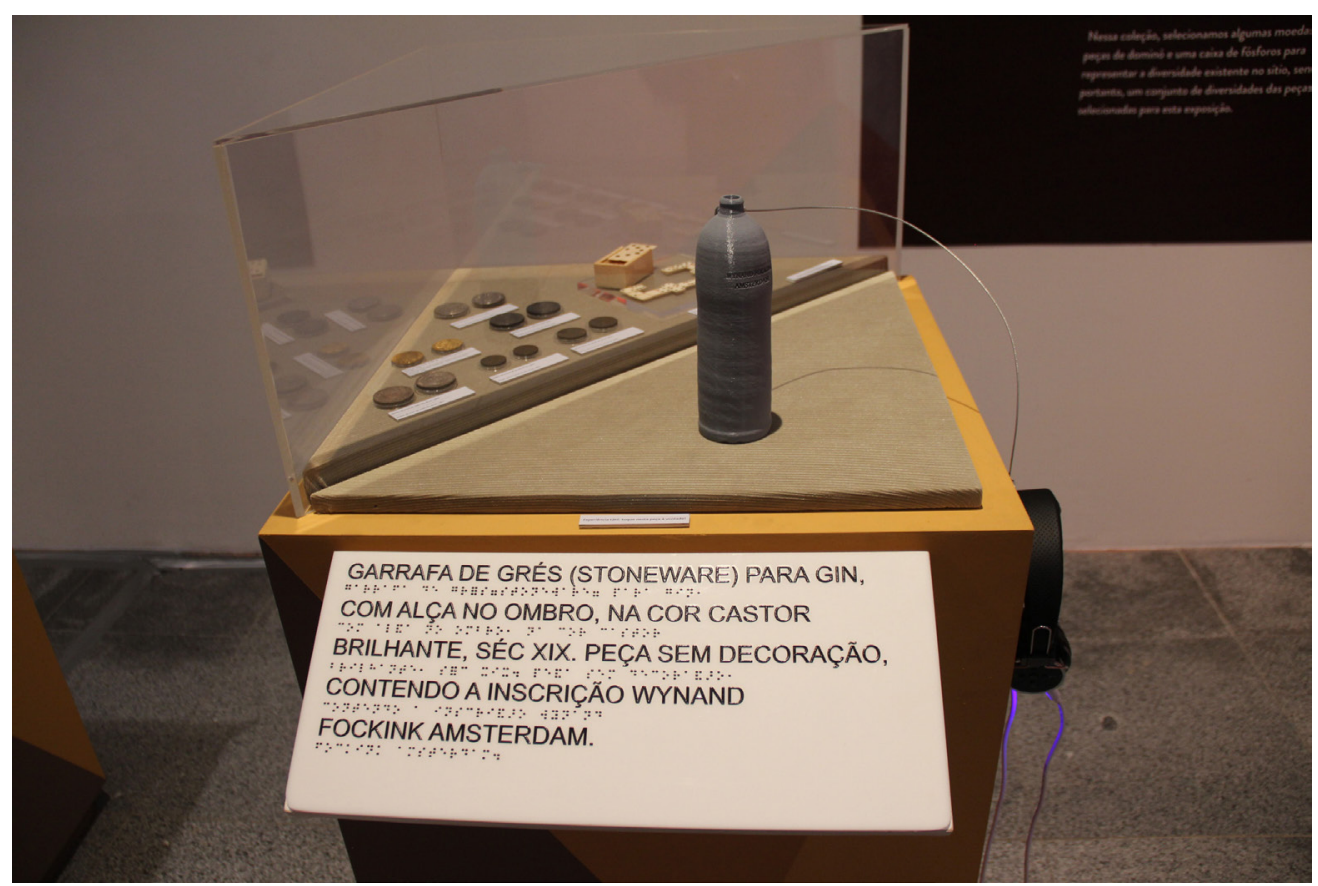

Figura 7 - Impressão 3D e reprodução holográfica de garrafa de grés, fabricada pela Wynand Fockink Amsterdam, Holanda, século XIX. Fotografia: Museu Histórico Nacional/lbram/MinC. 
36. Magalhães (2006, p. 31 e 67).

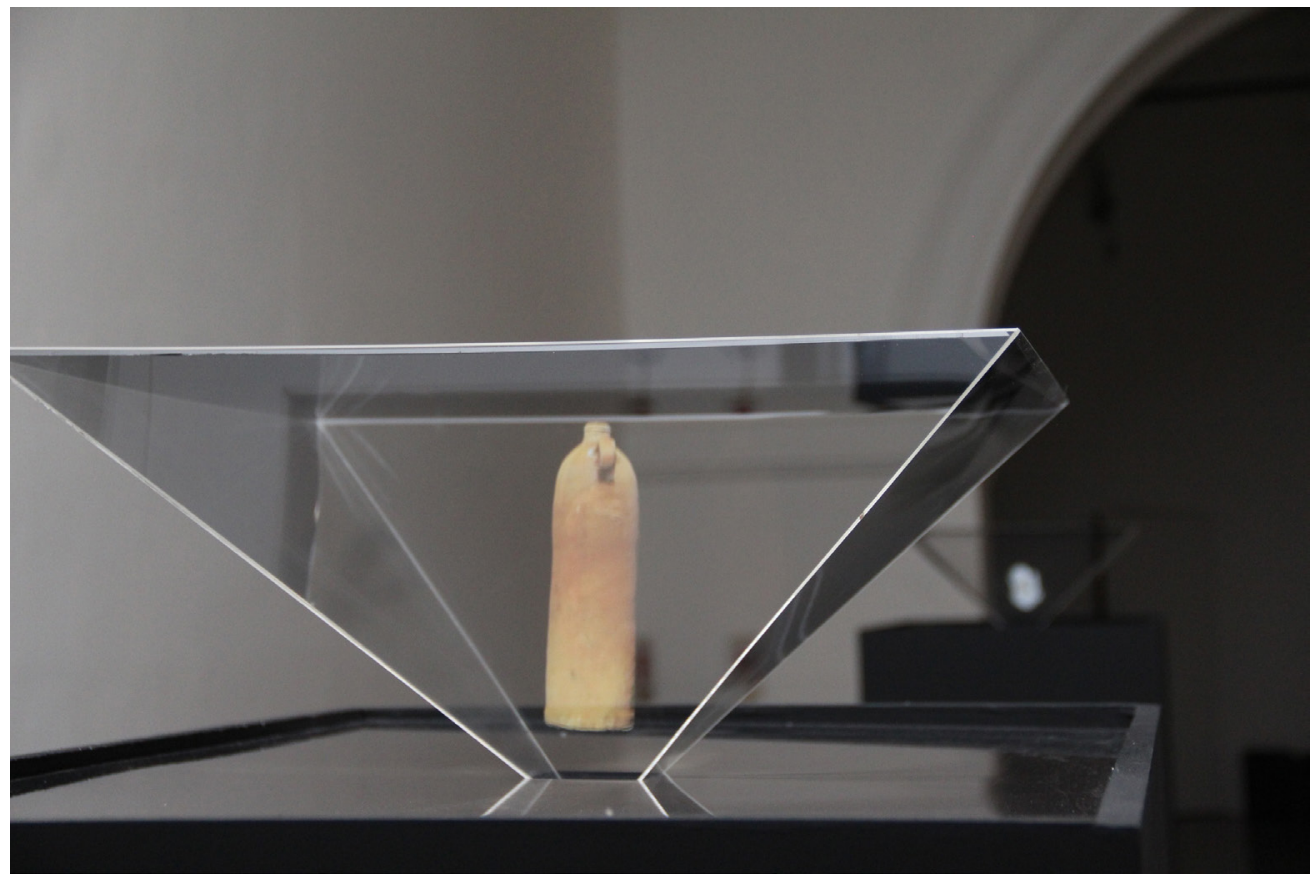

Figura 8 - Impressão 3D e reprodução holográfica de garrafa de grés, fabricada pela Wynand Fockink Amsterdam, Holanda, século XIX. Fotografia: Museu Histórico Nacional/Ibram/MinC.

Ressalte-se que, para além dos objetos virtuais, a exposição contou com peças do acervo do MHN que, por similaridade e contiguidade com os objetos expostos, transformaram-se em solução para pôr em cena a materialidade privada ao objeto arqueológico exposto de modo virtual. Optou-se por expor em uma vitrine, ao lado das representações virtuais, uma média de cinco artefatos provenientes das coleções do MHN que pudessem analogamente retratar, com características sensoriais materiais, os artefatos arqueológicos então indisponíveis. Este recurso de analogia foi utilizado para representar alguns dos objetos que fizeram parte da exposição, como a escova de dente, a garrafa de tíner e o cachimbo. Frise-se que, em alguns casos, o mesmo objeto foi representado mais de uma vez por diferentes recursos, como o cachimbo com a efígie de Ulysses $S$. Grant, cuja exibição foi proporcionada tanto pelo recurso da holografia, quanto pela impressão anaglífica que permite a visão tridimensional a partir de óculos 3D.

A missão de corporificar representações virtuais com o acervo do MHN não se provaria dificultosa, haja vista que a tônica da formação das coleções da instituição desde seus anos iniciais na década de 1920 se orientou pelo culto do passado do Estado Imperial, das Forças Armadas e da elite aristocrática na história nacional, ${ }^{36}$ provindo desses grupos os objetos a serem preservados "enquanto 
relíquias do nosso passado, cultuando a lembrança dos nossos grandes feitos e dos nossos grandes homens", ${ }^{37}$ segundo defendia Gustavo Barroso, fundador e diretor do MHN por quase quarenta anos. Assim sendo, os curadores da exposição, Manoel Vieira e Regiane Gambim, junto com técnicos do MHN, selecionaram trinta itens do acervo que se identificassem com o período histórico de funcionamento do Matadouro de São Cristóvão e que se referissem a práticas rotineiras dos habitantes da cidade no século XIX. Objetos como maçanetas em cristal brasonadas, pratos em faiança representando personagens ilustres da Guerra da Tríplice Aliança, pistola e aparatos de armaria, frascos de vidro de farmácia, azulejos residenciais, cachimbos, peças de dominó e uma escova de dente, além de um conjunto de moedas de ouro e prata, de diferentes valores, cunhadas no Brasil dos séculos XVII, XVIII e XIX, cumpriram a função de dialogar com os recursos digitais e as reproduções da exposição (Figura 9).

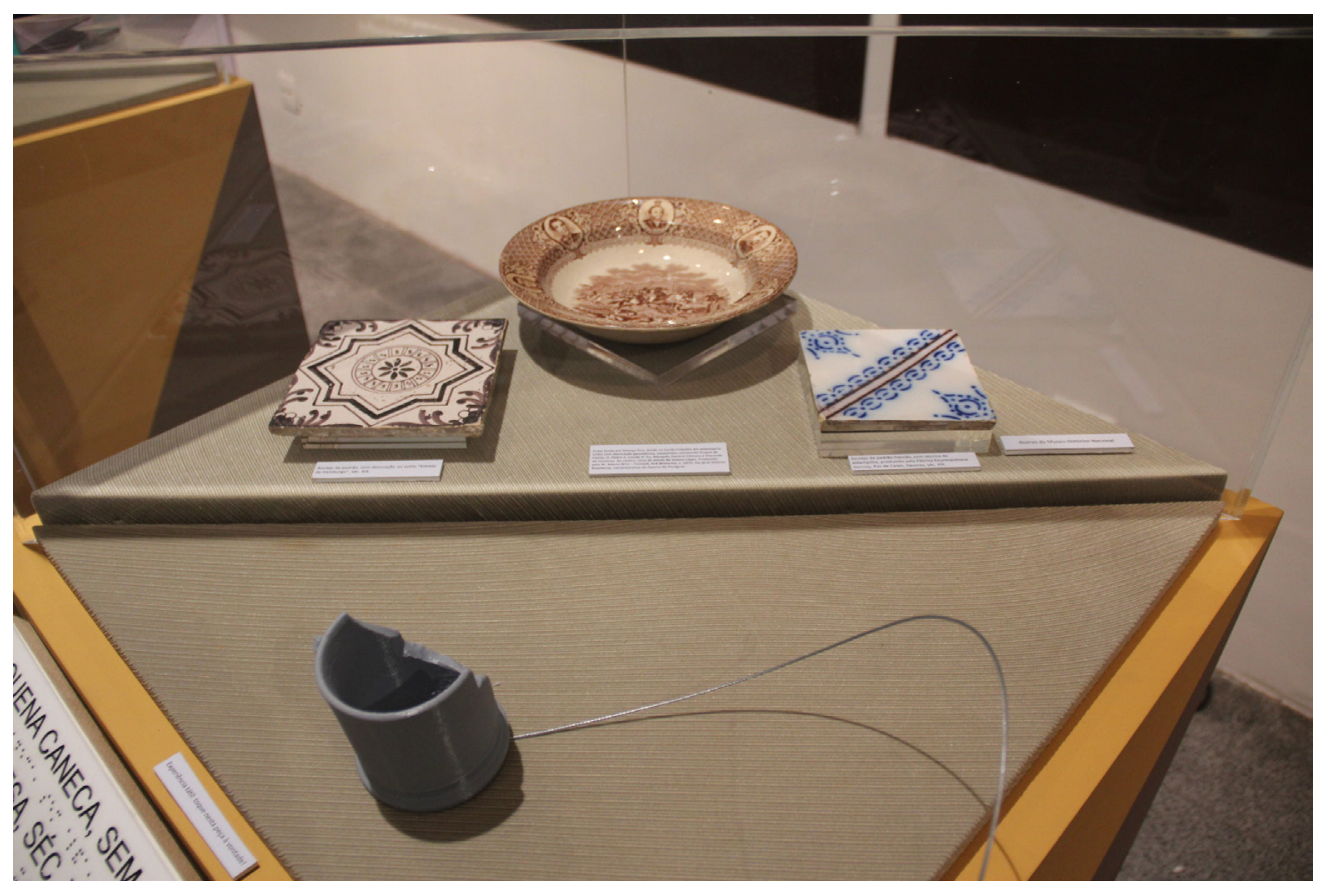

Figura 9 - Vitrine com acervo do Museu Histórico Nacional e impressão 3D de caneca sem alça. Fotografia: Museu Histórico Nacional/lbram/MinC.

Chame-se atenção para o fato de alguns desses objetos do MHN serem idênticos aos retirados na Leopoldina, mesmo que não tivessem sido obtidos por intermédio de escavação arqueológica. Ainda que o acervo arqueológico do MHN seja pouco significativo se comparado às suas coleções de história,
37. Barroso apud Magalhães (2006, p. 23) 
38. Bittencourt (2006, p. 255-256).

39. Pomian (1984, p. 6667).

40. Prefeitura da Cidade do Rio de Janeiro (2017, p. 5). destaque-se que a arqueologia esteve presente no programa do museu desde sua criação, graças às bases do conhecimento histórico de Gustavo Barroso, pautadas nas práticas oitocentistas do Instituto Histórico e Geográfico Brasileiro, o que incluía, portanto, o estudo da arqueologia. Ademais, parte do acervo inicial do MHN foi constituída por fragmentos arquitetônicos do bairro da Misericórdia, no Rio, peças de artilharia desenterradas pelo país afora e uma quantidade expressiva de moedas referentes à Antiguidade Clássica. ${ }^{38}$ Embora a interpretação desses resquícios fragmentares à luz da arqueologia nunca tenha sido aprofundada na instituição, esses objetos não deixam de guardar em sua raiz pontos de contato com o universo da arqueologia, como o caráter fracionário e a noção de evidência material de remanescentes do passado.

\section{A EXPOSIÇÃO DA AURA NA ERA DIGITAL}

Uma vez compreendida a trajetória dos achados da Leopoldina rumo à interlocução com os moradores do Rio e os visitantes da cidade através da exposição realizada no $M H N$, resta questionar nesse discurso museológico a ausência dos objetos originais extraídos do sítio arqueológico Matadouro de São Cristóvão para pensar o lugar da linguagem provida pelas NTIC na expografia e - lugar da presença material do objeto musealizado perante essa nova possibilidade expográfica com potencial de virtualização da matéria. Em outras palavras, precisase pensar o lugar do objeto arqueológico nessa exposição sobre arqueologia urbana no Rio de Janeiro, cuja finalidade era, precipuamente, operacionalizar uma via de compartilhamento, por meio dos artefatos, entre aquele que vê e a representação de um tempo pretérito, hoje já desmaterializado. ${ }^{39}$

O título da exposição "Achados da Leopoldina: arqueologia urbana na era digital" sugere uma justaposição de termos que, se não aparentemente assincrônicos, são no mínimo interessantes de serem lidos lado a lado. Enquanto a arqueologia, etimologicamente, é o estudo de objetos antigos, o digital evoca uma virtualidade do presente que escapa à analogia concedida ao artefato arqueológico. Lê-se no catálogo promocional da exposição que a iniciativa é "um trabalho inédito no Brasil, no qual o visitante é provocado a refletir sobre o passado olhando pelas lentes do futuro". $40 \bigcirc$ passado, representado pela arqueologia, e o futuro, representado pelo uso de plataformas e mídias digitais, lugares aparentemente dicotômicos, são o mote desta exposição que, mais por questões conjunturais do que por planejamento inicial, adota o meio digital como solução expográfica. 
Inaugura-se, a partir da justaposição dos dois termos à primeira vista antagônicos, um novo modo de pensar quando verificamos em um só signo expositivo a "representação virtualizada de um objeto arqueológico". Se o artefato arqueológico carrega a priori um valor de antiguidade e um valor de culto a um passado que não pode mais ser testemunhado, a não ser por meio do objeto que deste passado participou, para onde se desloca este valor quando, em vez da peça na sua materialidade, o que vemos no espaço museal é uma reprodução deste artefato mediada por linguagem virtual? Pode-se dizer que abordar expograficamente os artefatos de forma virtual ou através de uma reprodução carrega certa ironia, quando se trata de vestígios fragmentários do passado trazidos ao presente pela arqueologia.

A arqueologia destinou-se em seus primórdios, entre os séculos XV e XVII, ao estudo das coisas antigas, ${ }^{41}$ transmutando-se ao longo do tempo em estudo das culturas a partir de seu aspecto material. ${ }^{42}$ A arqueologia ganha, assim, outra dimensão, que compreende identificar, analisar e interpretar as coisas do passado enquanto estudo da cultura material, ou seja, dos vestígios da atividade humana materializados em artefatos, utensílios, estruturas de moradias, paisagem, restos de alimentação etc. ${ }^{43}$ A arqueologia passa, de tal sorte, a ampliar seu escopo de atuação e a trazer para o palco de seus debates em torno das mudanças das estruturas de forma, espaço e tempo da vida social ${ }^{44}$ a noção de memória material do passado. ${ }^{45}$

objeto arqueológico em sua condição fragmentária e lacunar, como um vestígio da ação humana incorporado às camadas da terra e, portanto, inexoravelmente afetado pelas atribulações do tempo ocasionadas ora pela mão do homem, ora pelas forças da natureza, converte-se em uma espécie de monumento da antiguidade per si. Ao definir, no início do século XX, uma teoria dos valores de culto ao monumento, ${ }^{46}$ Aloïs Riegl destacava como marca da modernidade de seu tempo o valor de antiguidade demandado pelo homem moderno na contemplação dos monumentos antigos para suprir sua satisfação estética ao se deparar com os ciclos de mudança da vida, despertando sua sensibilidade no plano subjetivo ao prezar pela constatação das marcas da imperfeição e pela visibilidade da dissolução das formas e das cores dos monumentos, ${ }^{47}$ tornando candentes as características de tempo decorrido, de ruptura, descontinuidade e, por fim, de vida e morte. ${ }^{48}$

$\bigcirc$ valor de antiguidade para Riegl representaria a evolução do valor histórico do monumento iniciada no Renascimento, quando a sociedade olhava para a Antiguidade Clássica com o intuito de identificar naquele passado a sua própria tradição artística, cultural e política. ${ }^{49} \bigcirc$ monumento adquiria, naquele período, importância por permitir àquela geração rememorar os feitos e destinos
41. Cf. Funari (2013).

42. Gaspar (2000, p. 7).

43. Cf. Funari (2013); Meneses (1984, p. 34).

44. Cf. Lima (2011).

45. Carvalho; Funari (2014, p. 195).

46. Riegl (2016).

47. Ibid., p. 22.

48. Ibid., p. 50-53.

49. Ibid., p. 27. 
50. Ibid., p. 9.

51. Le Goff (1990, p. 172).

52. Espaço de experiência: categoria meta-histórica complementar a "horizonte de expectativa", ambas cunhadas por Koselleck (2006a, p. 310). A primeira refere-se à aglomeração n ã o - e s tru tu ra d a cronologicamente de um passado composto por acontecimentos diversos, incorporados e lembrados por gerações sucessivas, formando o conhecimento histórico de determinado período; a segunda referese às intenções do olhar do momento presente em relação ao futuro como possibilidade de concretização daquilo que se entrevê e se projeta para o porvir.

53. Le Goff (1990, p. 196).

54. Koselleck (2006b, p. 267).

55. Cf. Huyssen (2000).

56. Cf. Hartog (2014, p. 214).

57. Id. (2006, p. 270).

58. Ibid., p. 265.

59. Ibid., p. 266; Le Goff (1990, p. 198); Nora (1993, p. 15). humanos de outrora. ${ }^{50}$ Entenda-se, no entanto, que a tomada de consciência dos humanistas em relação à ruptura com o passado medieval implicava concomitantemente um sentimento de modernidade que não se opunha ao passado, mas que o entendia como um progresso circular, de eterno retorno, ${ }^{51}$ por oposição à experiência de ruptura da modernidade descrita por Riegl, quando o progresso linear iluminista já começava a ser sentido como acelerado e desconectado do "espaço de experiência"52 de seus contemporâneos, ${ }^{53}$ impelindo-os a buscar um refúgio para o presente no passado, do qual os monumentos davam testemunho.

Se o contexto hodierno é marcado pelo avanço do capital de consumo, da mídia comercial e das tecnologias de armazenamento da informação, há que se enxergá-lo como decorrência exacerbada da própria modernidade, que não se sustentou em sua crença na filosofia da história, ${ }^{54}$ vindo a contribuir para a sensação de aceleração do tempo ${ }^{55}$ e deixando como via possível ao indivíduo contemporâneo, desamalgamado do contato intergeracional e temeroso do esquecimento de um passado atrofiado, a ancoragem na musealização para suprir o vazio de seu deslocamento em relação à tradição e a frouxidão dos laços de pertencimento por meio de uma verdadeira síndrome de memória. ${ }^{56}$

A concepção de achado arqueológico ratifica, por conseguinte, o valor de culto de antiguidade na atualidade no sentido em que a nossa modernidade presentista, ${ }^{57}$ ainda que em crise com os ideais das Luzes, refratária ao antigo e atraída pela novidade aportada pela tecnologia, ${ }^{58}$ tende a paradoxalmente abrigar-se na história, na memória e no patrimônio, 59 deixando patente a vontade de rememoração pela investigação da origem do objeto arqueológico, de sua contextualização no tempo e no espaço pretéritos e dos acontecimentos que levaram à sua sobreposição literal por outros estratos de vida. Tal tarefa, no entanto, está permeada pela compreensão do direito outorgado à natureza de atuar sobre esses objetos e de guardá-los para que o futuro possa se deleitar com os traços burilados sucessivamente por um tempo contado em séculos ou milênios sobre as obras humanas. Logo, ainda que nem sempre encontrados em sua inteireza física, tampouco contextual do sítio arqueológico, os artefatos suscitam uma tênue conexão entre a vida do homem contemporâneo e a de seus antecessores - se não dos hábitos de vida correlatos e dos usos de um mesmo espaço habitado, é do reconhecimento de si mesmo no espectro da história da humanidade que advém o sentimento de empatia por quem nunca sequer se conheceu.

Exatamente por se tratar de arqueologia, a ironia suscitada pelo uso da linguagem virtual "desmaterializante" sobre objetos musealizados - que tradicionalmente possuem o valor atribuído à coisa original em si - faz-se mais histriônica, posto que a disciplina avança a partir do estudo do mundo material, 
das coisas tangíveis que são tocadas e transformadas pelo homem. 60 Por outro lado, a arqueologia, ao tornar-se tema dos museus, evoca a particularidade da curadoria dessas peças no sentido em que guardam como traço comum seu reconhecimento ao acaso de descobertas ou, ainda, por meio de escavações metódicas. Elas são, portanto, produto de um descarte intencional ou não da cultura material produzida por pessoas do passado. ${ }^{61}$

Do museu que se proponha a falar de arqueologia, espera-se que proporcione ao observador a visualização do que restou fragmentariamente desse passado em peças e pedaços. ${ }^{62}$ Se os artefatos arqueológicos abrigados nos museus, "à primeira vista, não passam de cacos de coisas feitas por uma gente desaparecida, que não guarda relação alguma com a sociedade atual", ${ }^{3}$ deve-se, no entanto, reconhecer que é justamente dessa idiossincrasia que emergem tanto o desafio quanto a potência dos museus de arqueologia. As referências patrimoniais arqueológicas ganham outra dimensão no contexto museal, onde, submetidas à cadeia operatória de procedimentos museológicos de conservação, documentação, estudo e comunicação, ${ }^{64}$ podem contribuir - por sua recontextualização e por sua ressignificação através dos discursos e experiências expositivas - para a reflexão sobre a condição humana e o cultivo de noções de identidade e pertencimento entre indivíduos e sociedades afastadas temporalmente. ${ }^{65}$

Certo é que no museu esses resquícios de antão se convertem em "semióforos" 60 perdendo sua função original para adquirir novos sentidos sob o jugo do olhar alheio, isso graças à fratura entre sua proveniência de algum lugar no passado e seu achado, coleta e exposição no presente. Não obstante, a intenção em jogo parece sempre ter sido, até aqui, extrair ensinamentos sobre o estado primordial e relacional dessas coisas junto de outros conjuntos de objetos. ${ }^{67}$ Diferenciada, portanto, dos objetos comuns, a musealia reveste-se da função documental, 68 sendo os objetos de museu, segundo o teórico da museologia Zbynek Stránský, "autênticos testemunhos, documentos e/ou evidências de fatos naturais e sociais", 69 cujo valor documentário se expressa em um eixo temporal ao longo de sua existência, que acumula em sua estrutura material e formal os traços do tempo e dos eventos. ${ }^{70}$

Considerando-se que a exposição é o "main way through which museums deal with society, the activity that characterizes and legitimates the museum as such", 71 deve-se, ainda assim, atentar não só para a conjuntura social de produção da qual o artefato musealizado está privado, mas também para a nova visão da realidade engendrada pela própria linguagem museológica, talvez desvirtuada do contexto original, mas prenhe de novas significações simbólicas, ${ }^{72}$ que corroboram a função do museu como lugar de potencialização da fruição estética e documental ao fazer das fontes de informação do passado matéria de exposição. ${ }^{73}$
60. Cf. Funari (2013).

61. Pomian (1988, p. 59).

62. Id. (1984, p. 66-67).

63. Saladino (2015, p. 168).

64. Bruno (1997, p. 7).

65. Cf. Conselho Internacional de Monumentos e Sítios (1990); Bruno (1997, p. 7).

66. Semióforos: "objetos que não têm utilidade [...], mas que representam o invisível, são dotados de um significado, não sendo manipulados, mas expostos ao olhar, não sofrem usura" (Pomian, 1984, p. 71).

67. Pomian (1988, p. 59).

68. Cf. Loureiro; Loureiro (2013).

69. Stránsk? apud Loureiro; Loureiro (2013).

70. Maroevic apud Loureiro; Loureiro (2013).

71. Tradução livre: "principal meio pelo qual os museus lidam com a sociedade, a atividade que caracteriza e legitima o museu como tal" (Scheiner, 1991, p. 109).

72. Hernández (2010, p. 214).

73. Cf. Yepes apud Loureiro; Loureiro (2013). 
74. Benjamin (1994, p. $165-$ 196).

75. Ibid., p. 168-169.

76. Id., 1994.

77. Ibid., p. 169

78. Ibid., p. 168.

79. Heinich (2008, p. 35).

Tendo como horizonte essas premissas, analisemos em que medida a experiência museal possibilitada pela exposição "Achados da Leopoldina" propôsse a colaborar para o entendimento das coisas do passado ao compor sua narrativa por breves textos, mas prioritariamente por reproduções e projeções de imagens tanto do que fora o antigo matadouro quanto dos objetos encontrados no sítio arqueológico. Partindo-se da perspectiva de Walter Benjamin sobre as técnicas de reprodução da obra de arte, ${ }^{74}$ tal exposição veio a se concretizar como o triunfo dos meios técnicos de comunicação e de reprodução associados ao desejo de aproximar as massas das coisas às custas da destruição da aura do original. ${ }^{75}$

Ressalte-se que, conquanto os objetos arqueológicos bem como os objetos musealizados em sentido amplo tenham historicamente recorrido a suportes de toda sorte para trazê-los ao momento da recepção, ou seja, ao momento da representação expográfica, uma apresentação mais fiel ou uma reprodução de si em sua originalidade, a análise deste artigo toma por base um caso no qual a linguagem utilizada na exposição teve por função reproduzir, por completo e tecnicamente, o objeto aurático. Assim, toma-se por fundamento a linguagem virtual empregada aos "Achados da Leopoldina" como uma técnica de reprodução, capaz de substituir o objeto reproduzido por sua cópia, à luz do emprego dado ao termo por Walter Benjamin. ${ }^{76}$

Coube à sociologia da arte atualizar o pensamento de Benjamin com relação à obra de arte perante sua reprodutibilidade técnica. Enquanto o frankfurtiano percebia na possibilidade de cópias seriais das obras de arte um "violento abalo da tradição", 77 atualmente defende-se uma proporcional valorização da aura da obra diante da reprodutibilidade técnica. Por um lado, Benjamin afirma que

Mesmo que essas novas circunstâncias [aquelas proporcionadas pela reprodutibilidade técnica] deixem intato o conteúdo da obra de arte, elas desvalorizam, de qualquer modo, o seu aqui e agora. Embora esse fenômeno não seja exclusivo da obra de arte, podendo ocorrer, por exemplo, numa paisagem, que aparece num filme aos olhos do espectador, ele afeta a obra de arte em um núcleo especialmente sensível que não existe num objeto da natureza: sua autenticidade. ${ }^{78}$

Por outro lado, a socióloga Nathalie Heinich postula que os argumentos que embasam Benjamin a vislumbrar uma possível destruição da aura perante o avanço da reprodutibilidade técnica "são justamente a condição de existência dessa aura: é porque a fotografia multiplica as imagens que os originais ganham um status privilegiado". ${ }^{79}$ Assim, torna-se, mais uma vez, clara a relevância conferida por nossa 
sociedade ao "aqui e agora do original" 80 Para as discussões atuais da sociologia da arte, à medida que avança a reprodutibilidade técnica de uma obra, mais evidente torna-se sua aura. Notabiliza-se, pois, uma convergência entre o conceito de aura e o de valor de antiguidade. Resta, então, avaliar em que medida as técnicas de reprodução utilizadas pelas NTIC como recurso expográfico potencializam a aura do artefato arqueológico e, por conseguinte, o seu valor de antiguidade.

A experiência expositiva, impulsionada por variados recursos tecnológicos e lúdicos, sem dúvida propõe a interação no mínimo física com o exposto. No entanto, é inegável que aquilo que Riegl destacava como o valor de antiguidade que desperta a sensibilidade do homem moderno para o percurso da tradição evocado pela classe de monumentos marcada pela pátina do tempo, e cujo "aspect extérieur révèle de manière suffisante qu'elle existe depuis un certain temps et qu'elle a 'vécu"', 81 não logra ser nesse tipo de exposição vivenciado.

Reconhece-se, portanto, uma modificação da experiência de testemunhar o tempo passado ao não se defrontar com os objetos procedentes das entranhas das terras da Leopoldina. Não visualizar esses objetos em sua materialidade no percurso de uma exposição museológica, mas sim em seus simulacros, sugestiona a liquidação de sua existência única, do ato de presenciar o aqui e agora desses objetos, que comportam a experiência do tempo e da tradição iniciada desde sua origem, passando por sua duração material, até alcançar o estatuto de testemunho histórico em virtude do conteúdo expresso pelo aspecto material da coisa, o que Ihe outorga, finalmente, autoridade e peso de patrimônio da cultura. ${ }^{82}$

Prescindir da exposição do objeto original altera o sentido e a forma de rememorar a herança histórica de nossos antepassados tal como esta vinha sendo operacionalizada até recentemente pelos museus. Cabe afinal indagar se estamos, no seio de uma sociedade de consumo insaciável e seduzida pelos apelos da tecnologia, experimentando uma mudança no padrão desse culto moderno dos monumentos, em que bastaria a presença da imagem - efêmera e descartável. Operase ainda nos dias atuais dentro de uma lógica rememorativa dos monumentos, na qual, todavia, incorpora-se essa nova vertente para além da presença, quiçá até mesmo da existência do objeto. $\bigcirc$ monumento, enquanto forma e conteúdo laboriosamente trabalhado pelo homem e pelo decorrer do tempo, pouco soa importar em sua fisicalidade, desde que se transforme em valor de evolução da sociedade. ${ }^{83}$

Para o filósofo Andreas Huyssen, o código da nostalgia moderna pelo passado clássico seria a ruína. ${ }^{84}$ Segundo o autor, "no corpo da ruína, o passado está presente nos resíduos, mas ao mesmo tempo não está mais acessível, o que faz da ruína um desencadeante especialmente poderoso da nostalgia". ${ }^{85}$ Analogamente, o objeto arqueológico traz em sua materialidade a vontade de
80. Cf. Benjamin (1994).

81. Tradução livre: "aspecto exterior revele de maneira suficiente que ela existe há certo tempo e que ela 'viveu'" (Riegl, 2016, p. 2).

82. Benjamin (1994, p. $168-$ 169).

83. Riegl (2016, p. 33-34).

84. Huyssen (2014, p. 91).

85. Ibid., p. 91. 
86. Heinich (2008, p. 35).

87. Huyssen (2014, p. 97).

88. Prefeitura da Cidade do Rio de Janeiro (2017, p. 4).

89. Huyssen (2000, p. 17). memória da modernidade e sua obsessão pela passagem do tempo. Assim como para a ruína, o signo que representa a antiguidade é valorizado em sua materialidade, unicidade e, segundo Huyssen, em sua autenticidade.

Este valor de autenticidade aparece, então, como algo desejável nos objetos consumidos na modernidade, em consonância com o que prognostica Heinich, ${ }^{86}$ ao passo que avança a mediação da vivência e da experiência do mundo por meio da técnica. $\bigcirc$ objeto original assume um caráter de fetiche, se compreendemos o fetichismo como a capacidade de um objeto inanimado ser dotado, pelo sujeito, de algum sentido de culto. Cultua-se, então, o passado por meio do objeto arqueológico, ou da ruína, em seu imediatismo, e cultua-se a irreprodutibilidade, a impossibilidade da cópia, na obra de arte aurática. $\bigcirc$ fetiche do passado, segundo Huyssen, pode ser explicado a partir do fato de que "quanto mais aprendemos a compreender todas as imagens, palavras e sons como já sendo sempre mediados, mais parecemos desejar o autêntico e o imediato". ${ }^{87}$ Este trecho é revelador do caráter desejante da autenticidade pelo sujeito da modernidade, saturada de cópias e de reproduções inerentes a uma época na qual o suporte midiático é regra nas interações.

Logo, se há um valor de autenticidade na modernidade, que a conecta com um passado que ela não testemunhou, mas do qual se acredita herdeira, como explicar então a profusão de dispositivos digitais, novas plataformas midiáticas e aparatos tecnológicos que são, dia após dia, criados e adotados nos mais diversos campos do saber para mediar conexões? Em se tratando do campo do patrimônio e da memória, no qual a autenticidade e a não mediação costumam possuir valor de culto, reiteramos os questionamentos levantados anteriormente: de que modo a mediação por tecnologias de informação e comunicação digitais afeta este valor? E, para além, seria a mediação um novo valor de culto?

No mesmo catálogo a que nos referimos, da exposição "Achados da Leopoldina", depara-se sintomaticamente com o seguinte título de uma seção: "Curadoria colaborativa e exposição virtual: um novo fetiche?". ${ }^{88}$ Consideramos, então, a hipótese de que o uso das tecnologias digitais que configuram uma nova representação da "realidade" possa também ser hoje um fetiche. A exposição "Achados da Leopoldina" encampa uma mirada pautada pela concepção de tempo moderno sobre os objetos nela reproduzidos, tornando patente que as superações tecnológicas continuam a se apoderar do encantamento dos observadores e intensificam uma percepção da ordem do tempo contemporâneo marcada pela sensação de encolhimento desse tempo e do espaço vivido, ${ }^{89}$ quando, ao invés disso, a antiguidade dos objetos poderia colaborar no intuito de convocar o indivíduo para a crítica de um tempo que não se resume ao progresso infinito. 
Como alerta o filósofo italiano Massimo Canevacci, ${ }^{90}$ que se debruça sobre os fetichismos visuais do nosso tempo, para Freud, o fetiche cria um nexo ambíguo entre sedutor e aterrorizante, ou familiar e estranho. ${ }^{91}$ Pode-se entender que, ao mesmo tempo que o objeto de fetiche parece algo familiar, oriundo da mesma realidade em que nos encontramos, ele também apresenta algo de perturbador. Ao nos lançarmos sobre a história do sujeito observador perante o desenvolvimento das tecnologias imagéticas desde a invenção da câmara escura, no século XVIII, conforme faz Jonathan Crary, ${ }^{92}$ podemos vislumbrar um espectro entre familiaridade e estranheza pelo qual o olhar do observador se desloca ao longo dos últimos séculos. Se permanecermos neste esforço de analogia, compreenderemos que esta familiaridade se referiria à imagem retratada sem mediação, ou cuja mediação é imperceptível, e este perturbante seria a expressão do meio na representação da realidade, ou, em outras palavras, a evidência da mediação sobre o conteúdo.

Crary inicia sua análise sobre o observador a partir do que ele estabelece como a separação entre o tato e a visão, própria do início da modernidade. A mediação passa a possibilitar a visão independentemente da tatilidade do objeto ou do espaço ocupado pelo sujeito.

espetáculo, como tendência a fazer ver (por diferentes mediações especializadas) o mundo que já não se pode tocar diretamente, serve-se da visão como o sentido privilegiado da pessoa humana - o que em outras épocas fora o tato; o sentido mais abstrato, e mais sujeito à mistificação, corresponde à abstração generalizada da sociedade atual. [...] A perda do tato como componente conceitual da visão significou deslocar o olho da rede de referenciais encarnados na tatilidade e na sua relação subjetiva com o espaço percebido. Essa autonomia da visão, que ocorreu em muitos domínios diferentes, foi uma condição histórica para reconstruir um observador sob medida para as tarefas do consumo "espetacular". 93

Em seu livro Técnicas do observador, ${ }^{94}$ Crary situa desde a invenção da câmara escura até o surgimento da câmera fotográfica no século XIX; de momentos em que a realidade observada se pretendia uma representação fiel do mundo até momentos em que o truque maquínico não se ocultava; de períodos em que a representação do mundo era compreendida como externa ao observador a fases nas quais, a partir da fisiologia, o observador passa a ser elemento determinante na formação do mundo situada na retina. Tal separação entre tato e visão inaugura, então, uma era de mediações e reproduções técnicas características de um tempo embalado pela centralidade de signos e mercadorias móveis, no qual a rapidez, a volatilidade, a fluidez e a efemeridade são conceitos-chave de sua identidade exclusivamente óptica. ${ }^{95}$
90. Canevacci (2008).

91. Ibid., p. 246.

92. Crary (2012).

93. Ibid., p. 27.

94. Cf. Crary (2012).

95. Ibid., p. 66. 
96. Ibid., p. 126

97. Ibid., p. 130

98. Ibid., p. 27.

99. Ibid., loc. cit.

100. Ibid., loc. cit.

101. McLuhan (1969).

102. Benjamin (1994, p. 168).
Ao longo dos séculos XVIII e XIX surgem muitos dispositivos de reprodução imagética que ora se pretendem dispositivos de representação pura, ora se assumem dispositivos que fabricam experiências ilusórias. Ao situar estes dispositivos na história, Crary cita o estereoscópio, o primeiro equipamento de visão tridimensional, como uma ferramenta que "expunha abertamente a natureza alucinante e fabricada da experiência", 90 e atribui a esta característica ilusionista a transformação de seu uso em aparato de entretenimento e, seguidamente, em sua derrocada por ser "insuficientemente fantasmagórico". ${ }^{97} \bigcirc$ sujeito moderno parece tender a absorver na sua apreensão do mundo "real" as tecnologias que se pretendem objetivas em sua reprodução do mundo, em outras palavras, aquelas que se fundem ao seu aparato sensitivo, ou seja, ao seu corpo, de modo a potencializar seus sentidos, porém sem falseá-los ou iludi-los. Crary explica que, ao longo dos séculos XVII e XVIII, a relação entre sujeito e aparato técnico havia sido de caráter metafórico, na qual o dispositivo tecnológico faz as vezes do aparato orgânico, como a câmara escura que imita o funcionamento do olho. Já no século seguinte, a máquina funde-se ao orgânico, com a intenção de expandir e potencializar seu funcionamento. ${ }^{98}$

No começo do século XIX, a relação entre olho e aparato óptico torna-se metonímica: agora, ambos são instrumentos contíguos no mesmo plano de atuação, com capacidades e características variáveis. Os limites e as deficiências de um serão complementados pelas capacidades do outro e vice-versa. ${ }^{99}$

Da tecnologia como metáfora à tecnologia como a parte do corpo pelo todo, a modernidade inaugura o novo estatuto metonímico do sujeito. 100 Neste momento, remonte-se ao famoso livro de Marshall McLuhan, Os meios de comunicação como extensão do homem. ${ }^{101}$ Deixemos de lado, porém, a discussão sobre seu suposto determinismo tecnológico e atentemos ao título do livro, que é destrinchado em seu conteúdo para apresentar uma abordagem dos meios de comunicação como extensões dos sentidos humanos, sejam da fala, da visão, da audição, ou do tato. Os suportes comunicacionais surgem para, grosso modo, potencializar nossos sentidos e, de certa forma, tornálos possíveis quando a realidade física não os permite. Da perspectiva do campo do patrimônio, em consonância com Benjamin, "a reprodução técnica pode colocar a cópia do original em situações impossíveis para o próprio original". ${ }^{102}$ Voltando ao campo lato sensu da comunicação, usamos um telefone para nos fazer ouvir e poder ouvir alguém que, em condições estritamente orgânicas, não poderia ser ouvido ou se fazer ouvir devido à distância; vemos a Guerra do Vietnã televisionada do nosso sofá, como se nossos olhos e aparato visivo no Vietnã estivessem, e assim por diante. Ressalte-se, neste momento, que é parte de pesquisas recentes das ciências 
da comunicação a investigação acerca das alterações de recepção engendradas pelo desenvolvimento e implantação das NTIC na mediação dos discursos. ${ }^{103}$

De tal modo, a tecnologia é, para o sujeito moderno, entendida como uma extensão de seus sentidos quando contígua ao corpo em uma aparente organicidade, e como um objeto de fetiche e de curiosidade quando revela seu caráter inorgânico interferindo e modificando a realidade objetiva. Outros autores corroboram o pensamento de que o colapso da técnica da estereoscopia, por exemplo, estaria na ambivalência entre sua capacidade de criar uma tridimensionalidade aparentemente tangível e os limites aceitáveis da verossimilhança. ${ }^{104}$ "A estereoscopia teria sido vítima de sua própria 'magia', já que sua possibilidade de tridimensionalidade era apesar de tudo apenas um artifício". 105 Segundo Crary, o mesmo estranhamento gerado pela imagem estereoscópica é aquele que se vê no século XX, com o recebimento das tecnologias de holografia e $3 D$ por parte do público. ${ }^{106}$

Assim, voltamos ao questionamento: se trataria, afinal, da exposição de uma mera experiência da técnica pela técnica? Ou de uma exposição de tecnologias modernas - neste caso, digitais - de reprodutibilidade imagética, na qual os efeitos ilusórios da máquina são também parte do argumento expositivo, mais do que uma exposição de achados arqueológicos? Ou o uso das tecnologias de reprodução potencializam a aura do objeto arqueológico não corporificado no aqui e agora de sua originalidade? $\bigcirc$ título da mostra mais uma vez parece ensejar uma resposta. A tecnologia de reprodutibilidade imagética hoje, nos museus, como que fornece um modo de apreensão da realidade tal qual aquele do consumidor de imagens estereoscópicas do século XIX: uma visão entretida por aparatos de ilusão que, embora engendrem um caráter lúdico, um estranhamento positivo, um fetiche, não substituem a materialidade que o sujeito moderno indica ainda desejar como condição sine qua non para o objeto patrimonializado.

É nesse sentido que a escova de dente atribuída ao Imperador Pedro II, encontrada na pesquisa arqueológica e representada a partir de uma impressão em 3D, é exposta ao lado de uma escova de dente original de período semelhante. A exposição da impressão tridimensional, passível de manuseio pelo visitante, almeja dar conta de que no passado do Rio de Janeiro oitocentista essas escovas eram fabricadas em madeira e osso com cerdas animais e visa a reduzir o distanciamento em relação a nossa realidade da higiene bucal pós-Segunda Guerra Mundial. Procura-se, então, aproximar essas duas experiências distantes temporalmente pelo prosseguimento do hábito de escovar os dentes e pelo ato de segurar esse objeto de higiene pessoal mediado pela reprodução em 3D, que, entretanto, só de muito longe se acercaria das propriedades de peso, textura, cor, cheiro e, claro, sabor da escova de dente do Imperador (Figuras 10 e 11 ). 


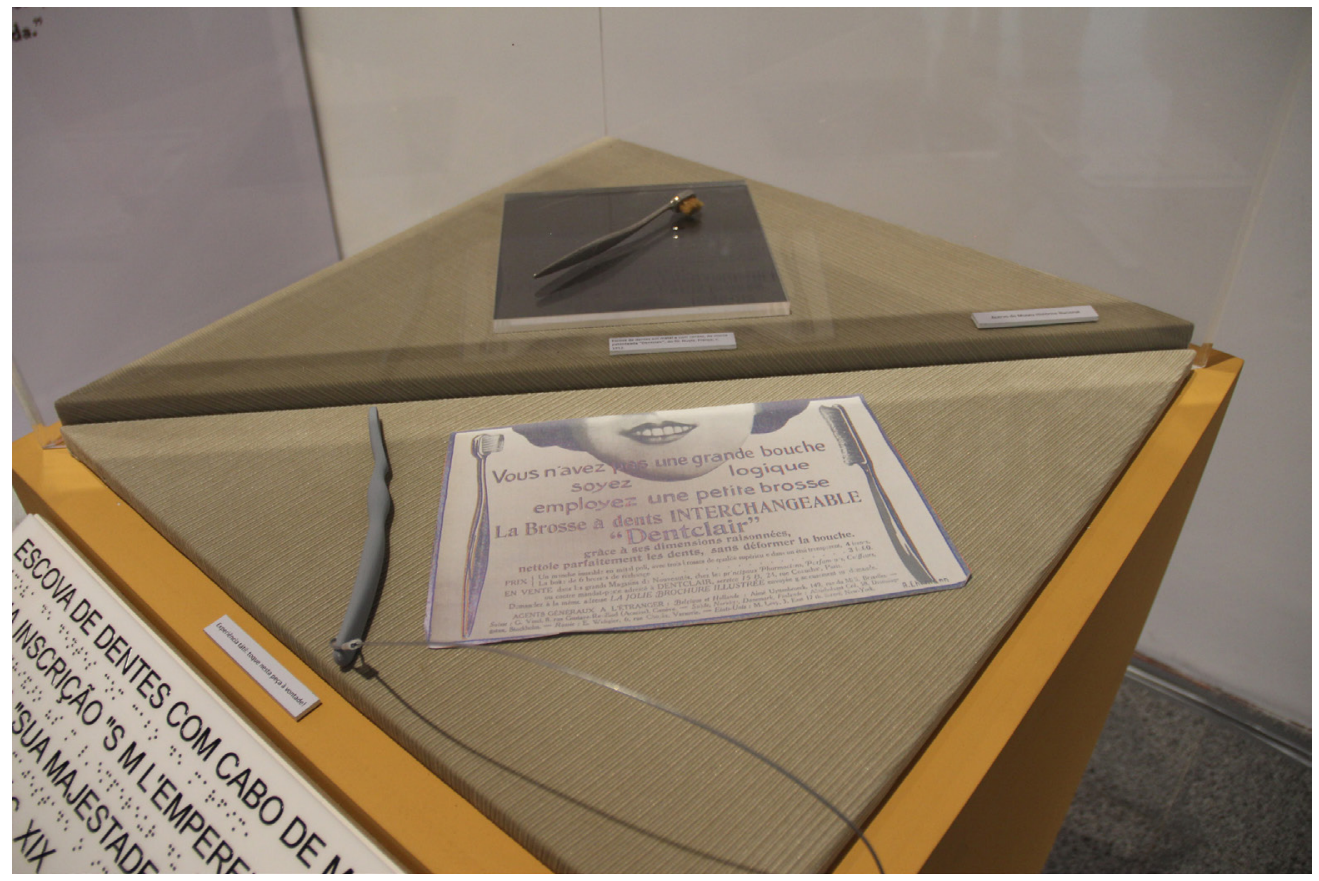

Figura 10 - Impressão 3D de escova de dente acompanhada de escova de dente de metal do acervo do MHN. Fotografia: Museu Histórico Nacional/Ibram/MinC.

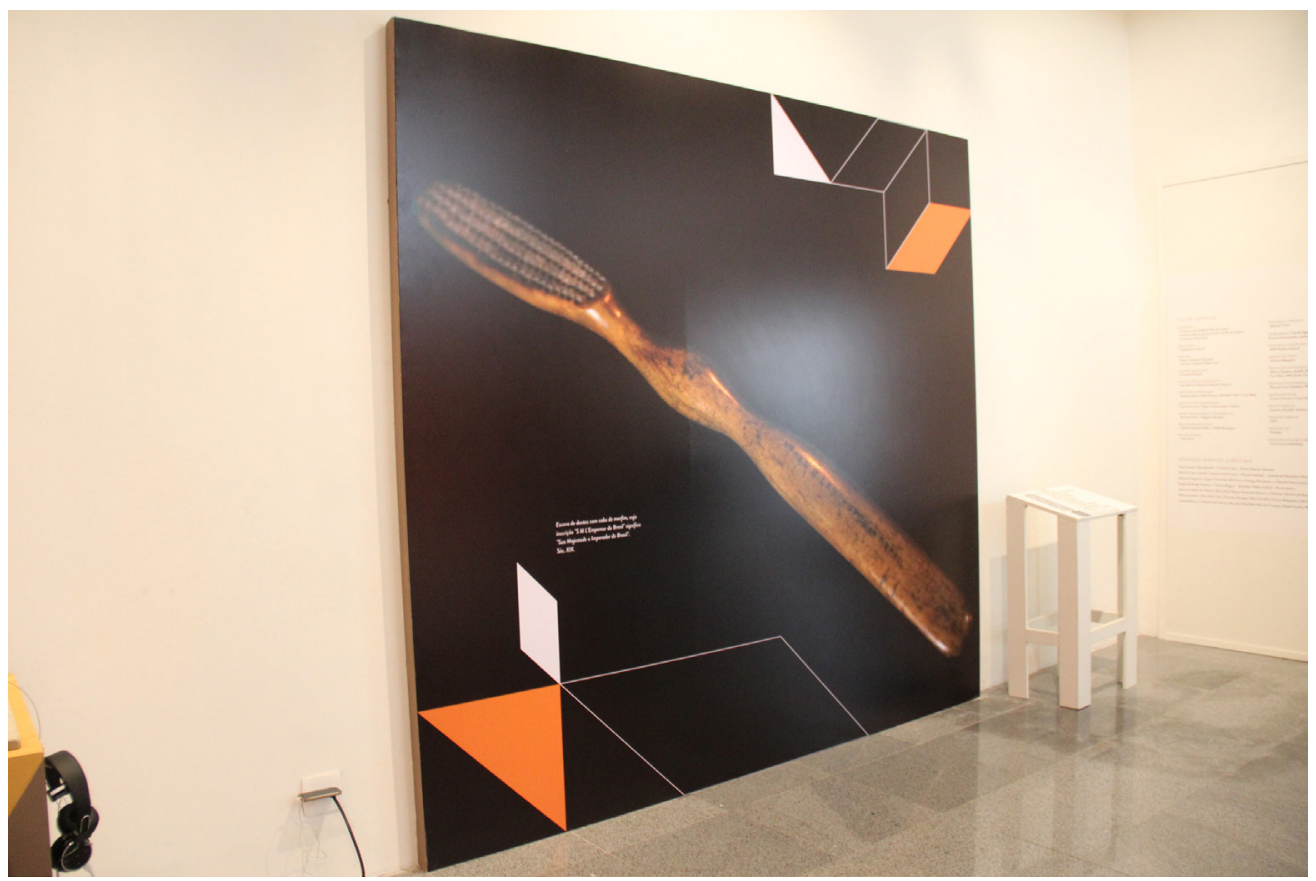

Figura 11 - Fotografia impressa em painel de escova de dente encontrada no Matadouro de São Cristóvão. Fotografia: Museu Histórico Nacional/lbram/MinC. 
Lembre-se ainda da realidade virtual projetada sobre o que o teria sido a antiga estrutura arquitetônica do prédio do Matadouro de São Cristóvão quando de sua plena atividade como abatedouro de gado no Segundo Reinado. Nada mais do que um esboço para tornar palpável ao olhar aquele espaço hoje desmobilizado, distante do entendimento de um público acostumado a comprar sua carne processada em bandejas de isopor embaladas a plástico e, a princípio, assepticamente protegidas de resquícios visíveis de sangue e do odor de morte do animal.

Atente-se para o fato de que os conteúdos de um objeto de museu compreendem tanto a autenticidade aurática de um passado marcado a ferro e fogo no corpo do objeto, tal como este é encontrado no momento de sua musealização, incluindo-se aí todo o seu percurso de criação e vida no mundo corrente, quanto a autenticidade não aurática dos discursos de que se reveste o patrimônio, ${ }^{107}$ as novas atribuições sociais de valor agregadas ao objeto a partir de sua incorporação ao acervo de um museu - dito de outra maneira, a sua musealidade, ou aquele "nonmaterial value or meaning of an object that gives us the reason for its musealization". 108 Por conseguinte, não há como se destronar o lugar daquele objeto "sempre igual e idêntico a si mesmo", 109 pois "a esfera da autenticidade, como um todo, escapa à reprodutibilidade técnica, e naturalmente não apenas à técnica". ${ }^{110}$

A relação entre museu e objetos é, de tal sorte, inextrincável, residindo a "vantagem peculiar do museu e de sua característica mais poderosa: o trabalho com o objeto" 111 na elaboração de estratos de sentido acerca da participação da cultura material na produção e na reprodução social. ${ }^{112}$ Recordemos, no que tange aos artefatos arqueológicos, que as origens da própria disciplina arqueologia estão mescladas ao desenvolvimento do colecionismo moderno ao longo dos séculos XV e XVI na Europa, bem como aos desdobramentos deste colecionismo revitalizados na forma embrionária dos museus também em processo de invenção entre o Renascimento e as Luzes. ${ }^{113}$

Sem desconsiderar os motivos institucionais para a lacuna ocasionada à exposição "Achados da Leopoldina", apesar de todo tipo de investimento em tecnologias disponíveis para sanar esse vazio, inclusive voltando o projeto expográfico para o "uso de diferentes plataformas e mídias", 114 de maneira a instigar o "público a estabelecer um elo lúdico, sensorial e interativo com o acervo, capaz de ressignificar a própria relação do observador com o objeto", 115 os organizadores da mostra não se esquivaram de solicitar ao MHN peças de seu acervo para integrar a exposição em pequenas vitrines em cada conjunto interativo.

A discussão proposta sobre o lugar do objeto original no museu parece uma vez mais ter sido comprovada por essa mesma exposição, que buscou dentro de suas limitações expandir o conhecimento do passado do sítio Matadouro de São Cristóvão através de reproduções nos mais variados formatos. Coube, ao fim e ao
107. Gonçalves (1988, p 267).

108. Tradução livre: "valor não-material ou o significado de um objeto que nos dá o motivo de sua musealização" (Maroevic, 1997, p. 121).

109. Benjamin (1994, p. 167).

110. Ibid., loc. cit.

111. Meneses (1994, p. 28).

112. Ibid., p. 12.

113. Schaer (1993, p. 11).

114. Prefeitura da Cidade do Rio de Janeiro (2017, contracapa).

115. Ibid., contracapa. 
116. Cf. Heinich (2008).

117. Cf. Nora (1993).

118. Meneses (1994, p. 1314). cabo, aos objetos do $M H N$ corporificar vicariamente o lugar reservado aos artefatos arqueológicos, abrindo uma nova cadeia de temporalidade calcada no objeto, e não em sua reprodução, de modo a problematizar o lugar da mediação por meio das NTIC no museu.

Neste caso, verifica-se que o uso de técnicas de reprodução digitais que proporcionaram a substituição do objeto original por sua cópia virtual foi fundamental para abrir ao público a exposição "Achados da Leopoldina: arqueologia urbana na era digital", haja vista a impossibilidade de exibir os originais. É possível que a aura dos artefatos arqueológicos retidos, como objetos com valor de antiguidade em meio a uma sociedade mediatizada, seja acrescida de status privilegiado. ${ }^{116}$ Entretanto, há que se considerar a possibilidade de o meio técnico de reprodutibilidade se tornar, ele mesmo, dotado de valor de culto, corporificando por si só a aura daquilo que o museu vem a expor. Esta dotação de aura à ferramenta tecnológica - a que chamamos de fetiche - permite à forma tornar-se o conteúdo da exposição, configurando-se, pois, como a problemática que perpassa a análise de "Achados da Leopoldina", vide a exibição de um mesmo objeto arqueológico por meio de diversas técnicas de reprodução ao longo da exposição.

\section{CONCLUSÕES}

A experiência vivenciada na exposição "Achados da Leopoldina: arqueologia urbana na era digital", abrigada pelo MHN, fomentou o questionamento acerca da relação do homem com a cultura material no cenário contemporâneo, marcado por nossa imersão no universo tecnológico em que, paradoxalmente, museus e sua linguagem por excelência - a exposição - ocupam lugar de destaque na tarefa de materializar e eternizar um passado que nos parece escapar. ${ }^{117} \bigcirc$ estatuto tradicional dos fragmentos e das ruínas dos objetos foram postos à prova pela tecnologia, que emerge como sintoma da cultura de nossa sociedade de consumo, dialogando inegavelmente em prol da valorização e da difusão de aspectos recônditos dos objetos originais, contudo, ainda sem ocupar o lugar do objeto aurático do museu.

A ausência dos objetos do sítio arqueológico do Matadouro de São Cristóvão enquanto matéria sólida, tornados presentes por seus substitutos digitais e impressos 3D, pouco diminui a função do museu no domínio da documentação. ${ }^{118}$ $\bigcirc$ original, mesmo que imperfeito e descontextualizado, como no caso das peças do $M H N$, ainda impulsiona o fazer e o pensar dos museus, cuja existência 
continuará a se justificar pela "necessidade de dar conta da apreensão sensorial, empírica, corporal, exigida pelo universo da cultura material". ${ }^{119}$

Os objetos do MHN entram em cena na exposição para desempenhar esse papel de tornar presente aquilo que o observador procura em um museu, ao passo que a técnica no plano das virtualidades, sem intervir nos objetos, vem para contribuir em nossa aproximação da ideia do que aqueles objetos foram no passado, sugerindo pela sua incompletude atual o lugar corrente que um dia ocuparam. Dotam, assim, nossa experiência expositiva do sentido vestigial e fugaz da existência humana sobre a Terra na forma da cultura material, e agregam o sentido do patrimônio cultural aos objetos, o que significa enaltecê-los por um lado, mas restringi-los por outro, a ponto de nem mesmo poderem "desempenhar o papel de intermediários entre os espectadores, quaisquer que eles sejam, e os habitantes de um mundo ao qual aqueles são exteriores", 120 como no embargo do lphan à exposição dos artefatos da Leopoldina.

A mediação por novas tecnologias digitais torna-se, então, mais evidente quando simula objetos em sua materialidade com alto valor de culto, como os artefatos arqueológicos ou museológicos em geral. Essas tecnologias parecem não substituir o objeto aurático no contexto do patrimônio da cultura material, o que de certo modo expõe a vontade de autenticidade do sujeito moderno, apesar do fetiche das NTIC, e revela o lugar do museu como um dos últimos redutos da aura benjaminiana - e da tatibilidade - em nossa modernidade prenhe de simulacros. Há que se considerar nos museus de hoje em que medida a técnica de reprodutibilidade está a serviço da apresentação do objeto musealizado, do patrimônio, e em que proporção este está a reboque de novas tecnologias que atraem, por si mesmas, por seu próprio valor de culto, o visitante ao museu e o profissional de museus ao seu uso não planejado.

Talvez "Achados da Leopoldina: arqueologia urbana na era digital" ainda possua um elo faltante por se completar. Suas lacunas e brechas engrandecem as discussões em torno das possibilidades tecnológicas aplicadas às exposições na contemporaneidade, sem, entretanto, abrir mão da relevância do signo expositivo museológico, que se mantém firme ali, pois como bem expressa Ulpiano Bezerra de Meneses, "sem museu com acervo, a inteligibilidade do mundo material sofreria rude golpe em qualquer sociedade complexa". ${ }^{121}$ Pode ser que a completude dessa exposição ocorra quando a pesquisa arqueológica da Leopoldina finalmente chegar a bom termo, liberando os objetos para traçar outras tantas narrativas possíveis no contexto museológico. Quem sabe, então, se poderá verificar a real ressonância da potência da mediação pela virtualização do artefato arqueológico musealizado. 


\title{
REFERÊNCIAS
}

\author{
FONTES IMPRESSAS
}

ANDRADE, Marcela de et al. Relatório de acompanhamento da transferência do material arqueológico. Projeto de Salvamento Arqueológico do Sítio Matadouro Imperial de São Cristóvão, relativo ao Empreendimento de Interligação da Linha 4 Sul e Linha 1 do metrô do Rio de Janeiro. Rio de Janeiro, 3-5 e 11-12 fev. 2016. Arquivo da Superintendência do Iphan.

ATA de reunião realizada em 5 de setembro de 2013 no Sítio Arqueológico do Matadouro de São Cristóvão. Rio de Janeiro, 2013. Arquivo da Superintendência do Iphan.

COSTA, Mônica da. [Ofício $n^{\circ}$ 0095/16/GAB/IPHAN-RJ, acusando recebimento dos relatórios parciais do Projeto de Salvamento no Sítio Arqueológico do Matadouro Imperial de São Cristóvão]. Destinatários: Claudio Prado de Mello, Carlos Roberto de Figueiredo Osório, Marco Antônio de Lima Rocha, Maurício Rizzo. Rio de Janeiro, 15 jan. 2016. Arquivo da Superintendência do Iphan.

LIMA, Bento José de. [Carta 036/2012, solicitando extensão da cessão de uso do espaço da Estação Leopoldina para a RioTrilhos]. Destinatário: Carlos Eduardo Carneiro Macedo. Rio de Janeiro, 14 maio 2012. Arquivo da Superintendência do Iphan.

MACHADO, Vera Lúcia de Sá; SCARAMELLA, Giovani; RODRIGUES, Nídia. Ficha de Registro de Sítio Arqueológico do Matadouro Público de São Cristóvão. Rio de Janeiro, 8 dez. 2009. Arquivo da Superintendência do Iphan.

MELLO, Claudio Prado de. Projeto de salvamento arqueológico do Matadouro Imperial de São Cristóvão relativo ao empreendimento de interligação da Linha 4 Sul e a Linha 1 do Metrô da Cidade do Rio de Janeiro. Rio de Janeiro, out. 2012. Arquivo da Superintendência do Iphan.

MELLO, Claudio Prado de. Proposta de recomendações de proteção para o sítio arqueológico do Matadouro Imperial - Leopoldina. Rio de Janeiro, 7 ago. 2013. Arquivo da Superintendência do Iphan.

MELLO, Claudio Prado de. Relatório de pesquisa do projeto de arqueologia do sítio arqueológico da Leopoldina relacionado ao empreendimento de interligação da Linha 4 Sul e a Linha 1 do Metrô da Cidade do Rio de Janeiro. Rio de Janeiro, mai. 2016. Arquivo da Superintendência do Iphan. 
PROJETO de Salvamento Arqueológico do Sítio Matadouro Imperial de São Cristóvão, relativo ao Empreendimento de Interligação da Linha 4 Sul e Linha 1 do Metrô do Rio de Janeiro. Rio de Janeiro, 2012. Processo 01500.004936/2012-83. Arquivo da Superintendência do Iphan.

RIBEIRO, Viviane Magno. Memória de vistoria do Ministério Público Federal e de reunião realizada ao Laboratório de Arqueologia Brasileira (LAB). Rio de Janeiro, 16 nov. 2016. Arquivo da Superintendência do Iphan.

RIZZO, Maurício. [Ofício PRES - 210/2013, encaminhando Proposta de recomendações de proteção para o Sítio do Matadouro Imperial]. Destinatário: Ivo Barreto. Rio de Janeiro, 20 ago. 2013. Arquivo da Superintendência do Iphan.

RIZZO, Maurício. [Ofício PRES - 069/2016, informando sobre entrega do material arqueológico no $L A B]$. Destinatária: Mônica da Costa. Rio de Janeiro, 17 fev. 2016. Arquivo da Superintendência do Iphan.

RODRIGUES, Maria Christina Rodrigues. [Parecer $n^{\circ}$ 174/16/Arqueol/Iphan-RJ, sobre o relatório final do Projeto de Salvamento Arqueológico do Sítio Matadouro Imperial de São Cristóvão]. Destinatária: Cynthia Tarisse Fontoura. Rio de Janeiro, 27 maio 2016. Arquivo da Superintendência do Iphan.

ROSA, Carla. [Ofício s/n, denunciando irregularidades contratuais da empresa Terra Brasilis quanto ao Endosso Institucional do LAB]. Destinatário: Ivo Barreto. Rio de Janeiro, 20 ago. 2013. Arquivo da Superintendência do Iphan.

TERMO de Ajustamento de Conduta - Inquérito Civil n ${ }^{\circ}$ 1.30.001.001088/2016-58, assinado por Sérgio Gardenghi Suiama (compromitente), Claudio Prado de Mello (compromissário) e Jeanne Cordeiro (interveniente anuente). Rio de Janeiro: 24 mar. 2017. Arquivo da Superintendência do Iphan.

\section{LEGISLAÇÃO E DOCUMENTOS PATRIMONIAIS}

BRASIL. Lei n ${ }^{\circ}$ 3.924, de 26 de julho de 1961. Dispõe sobre os monumentos arqueológicos e pré-históricos nacionais. In: Instituto do Patrimônio Histórico e Artístico Nacional. Coletânea de leis sobre preservação do patrimônio. Rio de Janeiro: Iphan, p. 25-32, 2006.

BRASIL. Resolução Conama n $^{\circ}$ 001, de 23 de janeiro de 1986. Dispõe sobre critérios básicos e diretrizes gerais para a avaliação de impacto ambiental. Diário Oficial da União, Brasília, DF: Poder Executivo, Seção 1, p. 2548-2549, 17 fev. 1986. Disponível em: <https://bit. ly/2qyuX23>. Acesso em: 10 dez. 2018. 
BRASIL. Portaria $n^{\circ} 12$, de 11 de março de 2013. Expede permissão aos arqueólogos coordenadores dos projetos de pesquisa arqueológica. Diário Oficial da União, Brasília, DF: Poder Executivo, Seção 1, n. 48, p. 9, 12 mar. 2013. Disponível em: <https://bit.ly/2Ca4Hlf>. Acesso em: 10 dez. 2018.

CONSELHO INTERNACIONAL DE MONUMENTOS E SÍTIOS. Carta de Lausanne. Lausanne: Icomos-IFLA, 1990. Disponível em: <https://bit.ly/2QaXYQp>. Acesso em: 4 dez. 2018.

INSTITUTO ESTADUAL DO PATRIMÔNIO CULTURAL. Bens tombados: pórtico do antigo Matadouro Público. Rio de Janeiro: Inepac, 2018. Disponível em: <https://bit.ly/2Ru4gaB>. Acesso em: 4 dez. 2018.

INSTITUTO DO PATRIMÔNIO HISTÓRICO E ARTÍSTICO NACIONAL. Portaria n ${ }^{\circ}$ 07, de $1^{\circ}$ de dezembro de 1988. Estabelece os procedimentos necessários à comunicação prévia, permissões e autorizações para pesquisas e escavações em sítios arqueológicos e pré-históricos. Diário Oficial da União: seção 1, Brasília, DF, p. 24479, 15 dez. 1988. Disponível em: <https:// bit.ly/2BPgO7d>. Acesso em: 15 fev. 2018.

INSTITUTO DO PATRIMÔNIO HISTÓRICO E ARTÍSTICO NACIONAL. Portaria nº 230, de 17 de dezembro de 2002. Estabelece os procedimentos para obtenção de licenças ambientais compatíveis com os estudos preventivos de arqueologia. Diário Oficial da União: seção 1, Brasília, DF, p. 32, 18 dez. 2002. Disponível em: <https://bit.ly/2RzGWYU>. Acesso em: 4 dez. 2018.

MUSEU HISTÓRICO NACIONAL. Instituto Brasileiro de Museus. Plano museológico (20162019). Rio de Janeiro: Ministério da Cultura, 2016.

ORGANIZAÇÃO DAS NAÇÕES UNIDAS PARA A EDUCAÇÃO, A CIÊNCIA E A CULTURA. Recomendação referente à proteção e promoção dos museus e coleções, sua diversidade e seu papel na sociedade. Paris: Unesco, 2015. Disponível em: <http://www.icom.org.br/wp-content/ uploads/2017/05/RecomendacaoProtecaoMuseuseColecoes.pdf>. Acesso em: 11 dez. 2018.

LIVROS, ARTIGOS E TESES

BARASH, Jeffrey Andrew. Virtual experience, collective memory, and the configuration of the public sphere through the mass media: the example of Ex-Yugoslavia. In: Configurações, Braga, n. 17, p. 11-29, 2016. Disponível em: <https://bit.ly/2KVduu2>. Acesso em: 4 dez. 2018.

BENJAMIN, Walter. A obra de arte na era de sua reprodutibilidade técnica. In: BENJAMIN, Walter. Obras escolbidas I: magia e técnica, arte e política. São Paulo: Brasiliense, 1994. p. 165-196. 
BITTENCOURT, José Neves. Arqueologia brasileira no Museu Histórico Nacional: levantando algumas questões. Anais do Museu Histórico Nacional, Rio de Janeiro, n. 38, p. 254-262. 2006. Disponível em: <https://bit.ly/2QbVdyA>. Acesso em: 4 dez. 2018.

BRUNO, Maria Cristina Oliveira. Museologia e museus: princípios, problemas e métodos. Cadernos de Sociomuseologia, Lisboa, v. 10, n. 10, p. 7-11, 1997.

CALDARELLI, Solange Bezerra; SANTOS, Maria do Carmo dos. Arqueologia de contrato no Brasil. Revista USP, São Paulo, n. 44, p. 52-73, 1999-2000.

CANEVACCI, Massimo. Fetichismos visuais: corpos erópticos e metrópole comunicacional. São Paulo: Ateliê, 2008.

CARVAlHO, Aline Vieira de; FUNARI, Pedro Paulo. Inclusión en la arqueología pública brasileña: apuntes sobre prácticas colaborativas. In: RIVOLTA, María Clara (org.). Multivocalidad y activaciones patrimoniales en arqueología: perspectivas desde Sudamérica. Buenos Aires: Fundación de Historia Natural Félix de Azara, 2014. p. 193-216.

CARVALHO, Victa de. Pontos de vista: modernidade e visão estereoscópica. In: ENCONTRO NACIONAL DE HISTÓRIA DA MíDIA, 2006, São Luís. Anais [...]. Porto Alegre: ALCAR-UFRGS, 2006. p. 1-13.

CRARY, Jonathan. Técnicas do observador: visão e modernidade no século XIX. Rio de Janeiro: Contraponto, 2012.

FUNARI, Pedro Paulo. Arqueologia no Brasil e no mundo: origens, problemáticas e tendências. Ciência e cultura, São Paulo, v. 65, n. 2, p. 23-25, 2013.

GASPAR, Maria Dulce. Sambaqui: arqueologia do litoral brasileiro. Rio de Janeiro: Jorge Zahar, 2000.

GONÇALVES, José Reginaldo Santos. Autenticidade, memória e ideologias nacionais: o problema dos patrimônios culturais. Estudos históricos, Rio de Janeiro, v. 1, n. 2, p. 264-275, 1988.

HARTOG, François. Tempo e patrimônio. Varia bistória, Belo Horizonte, v. 22, n. 36, p. 261$273,2006$.

HARTOG, François. Regimes de historicidade: presentismo e experiências do tempo. Belo Horizonte: Autêntica, 2014. 
HEINICH, Nathalie. A sociologia da arte. Bauru: Edusc, 2008.

HERNÁNDEZ, Francisca Hernández. Los museos arqueológicos y su museografía. Gijón: Trea, 2010.

HUYSSEN, Andreas. A nostalgia das ruínas. In: HUYSSEN, Andreas. Culturas do passadopresente: modernismos, artes visuais, políticas da memória. Rio de Janeiro: Contraponto, 2014. p. 91-114.

HUYSSEN, Andreas. Seduzidos pela memória: arquitetura, monumentos, mídia. Rio de Janeiro: Aeroplano, 2000.

KOSELLECK, Reinhart. Espaço de experiência e horizonte de expectativa: duas categorias históricas. In: KOSELLECK, Reinhart. Futuro passado: contribuição à semântica dos tempos históricos. Rio de Janeiro: Contraponto, 2006a. p. 305-329.

KOSELLECK, Reinhart. Modernidade: sobre a semântica dos conceitos de movimento na modernidade. In: KOSELLECK, Reinhart. Futuro passado: contribuição à semântica dos tempos históricos. Rio de Janeiro: Contraponto, 2006b. p. 267-303.

LE GOFF, Jacques. História e memória. Campinas: Unicamp, 1990.

LIMA, Tania Andrade. Cultura material: a dimensão concreta das relações sociais. In: Boletim do Museu Paraense Emílio Goeldi, Belém, v. 6, n. 1, p. 11-23, 2011.

LOUREIRO, Maria Lucia de Niemeyer Matheus; LOUREIRO, José Mauro Matheus. Documento e musealização: entretecendo conceitos. Midas, Évora, n. 1, p. 1-14, 2013.

MAGALHÃES, Aline Montenegro. Culto da saudade na Casa do Brasil: Gustavo Barroso e o Museu Histórico Nacional (1922-1959). Fortaleza: Museu do Ceará, 2006.

MAROEVIC, Ivo. O papel da musealidade na preservação da memória. In: ANNUAL MEETING OF THE INTERNATIONAL COMMITTEE ON MUSEOLOGY - ICOFOM, 19., 1997, Paris. Study Series [...]. Paris: Ministère de la Culture, 1997. p. 120-125.

McLUHAN, Marshall. Os meios de comunicação como extensão do homem. São Paulo: Cultrix, 1969.

MENESES, Ulpiano Bezerra de. Do teatro da memória ao laboratório da História: a exposição museológica e o conhecimento histórico. Anais do Museu Paulista, São Paulo, v. 2, p. 9-42, 1994. 
MENESES, Ulpiano Bezerra de. Identidade cultural e arqueologia. Revista do Patrimônio, Brasília, DF, n. 20, p. 33-36, 1984.

NORA, Pierre. Entre memória e história: a problemática dos lugares. Revista Projeto História, São Paulo, n. 10, p. 7-26, 1993.

PERTHES, Boucher de. Antiquités celtiques et antédiluviennes, mémoire sur l'industrie primitive et les arts à leur origine. Abbeville: Briez, 1857.

POMIAN, Krzyzstof. Coleção. In: ENCICLOPÉDIA EINAUDI. Lisboa: Imprensa Nacional, v. 1, p. 51-86, 1984.

POMIAN, Krzyzstof. Musée archéologique: art, nature, histoire. Le débat, Paris, n. 49, p. 57-68, 1988.

PREFEITURA DA CIDADE DO RIO DE JANEIRO. Catálogo da exposição "Achados da Leopoldina: arqueologia urbana na era digital". Rio de Janeiro: Prefeitura da Cidade do Rio de Janeiro, 2017.

RIEGL, Aloïs. Le culte moderne des monuments: sa nature et ses origines. Paris: Allia, 2016.

SALADINO, Alejandra. Museus e arqueologia: algumas reflexões sobre a preservação e valorização dos bens arqueológicos. Revista Tempo Amazônico, Amapá, v. 3, n. 1, p. 159-177, 2015.

SCHAER, Roland. L'invention des musées. Paris: Gallimard, 1993.

SCHEINER, Tereza. Museums and exhibitions: appointments for a theory of feelings. In: ANNUAL MEETING OF THE INTERNATIONAL COMMITTEE ON MUSEOLOGY - ICOFOM, 13., 1991. Vevey. Study Series [...]. Vevey: ICOM, 1991. p. 109-113.

WICHERS, Camila de Azevedo Moraes. Museus e antropofagia do patrimônio arqueológico: (des)caminhos da práticas brasileira. 2010. Tese (Doutorado em Museologia) - Universidade Lusófona de Humanidades e Tecnologias, Lisboa, 2010.

Artigo apresentado em 23/03/2018. Aprovado em 11/10/2018

\section{(cc) BY}

All the contents of this journal, except where otherwise noted, is licensed under a Creative Commons Attribution License 